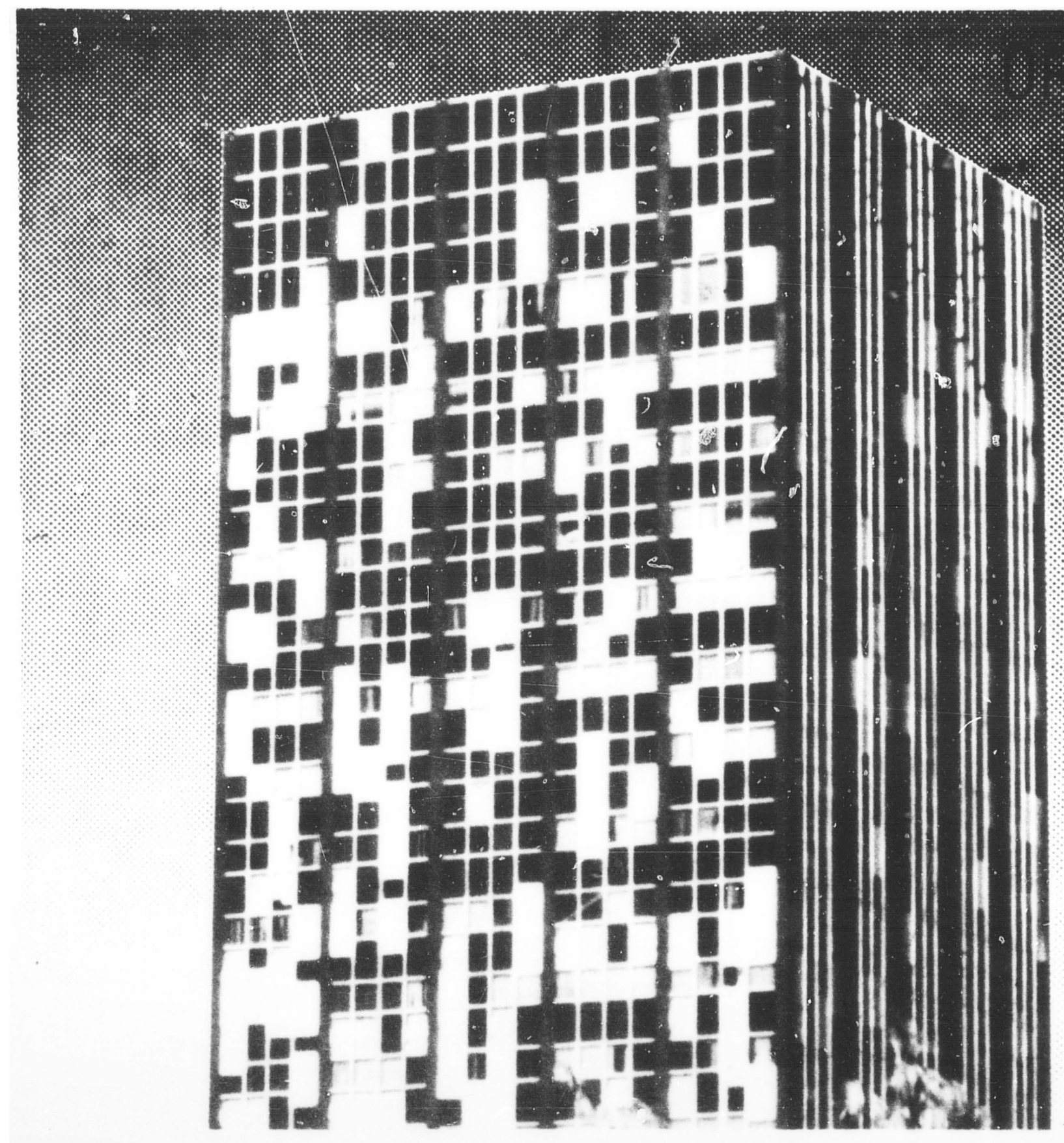

NBS BUILDING SCIENCE SERIES 154

\title{
Wind Loading \\ and Strength of Cladding Glass
}




\section{NATIONAL BUREAU OF STANDARDS}

The National Bureau of Standards' was established by an act of Congress on March 3, 1901. The Bureau's overall goal is to strengthen and advance the Nation's science and technology and facilitate their effective application for public benefit. To this end, the Bureau conducts research and provides: (1) a basis for the Nation's physical measurement system, (2) scientific and technological services for industry and government, (3) a technical basis for equity in trade, and (4) technical services to promote public safety. The Bureau's technical work is performed by the National Measurement Laboratory, the National Engineering Laboratory, and the Institute for Computer Sciences and Technology.

THE NATIONAL MEASUREMENT LABORATORY provides the national system of physical and chemical and materials measurement; coordinates the system with measurement systems of other nations and furnishes essential services leading to accurate and unitorm physical and chemical measurement throughout the Nation's scientitic community, industry, and commerce; conducts materials research leading to improved methods of measurement, standards, and data on the properties of materials needed by industry, commerce, educational institutions, and Government: provides advisory and research services to other Government agencies; develops, produces, and distributes Standard Reference Materials; and provides calibration services. The Laboratory consists of the following centers:

\section{Absolute Physical Quantities: - Radiation Research -- Chemical Physics Analytical Chemistry - Materials Science}

THE NATIONAL ENGINEERING LABORATORY provides technology and technical services to the public and private sectors to address national needs and to solve national problems; conducts research in engineering and applied science in support of these efforts; builds and maintains competence in the necessary disciplines required to carry out this research and technica! service: develops engineering data and measurement capabilities; provides engineering measurement traceability services; develops test methods and proposes engineering standards and code changes; develops and proposes new engineering practices; and develops and improves mechanisms to transfer results of its research to the ultimate user. The Laboratory consists of the following centers:

Applied Mathematics Electronics and Electrical Engineering - Manufacturing Engineering - Building Technology Fire Research - Chemical Engineering

THE INSTITUTE FOR COMPUTER SCIENCES AND TECHNOLOGY :onducts research and provides scientific and technical services to aid Federal agencies in thu selection. acquisition, application, and use of computer technology to improve effectiveness and economy in Government operations in accordance with Public Law 89-306 (40 U.S.C. 759). relevant Executive Orders, and other directives: carries out this mission by managing the Federal Information Processing Standards Program, developing Federal ADP standards s.uidelines, and managing Federal participation in ADP voluntary standardization activities: provides scientific and technological advisory services and assistance to Federal agencies; and provides the technical foundation for computer-related policies of the Federal Government. The Institute consists of the following centers:

Prugramming Science and Technology - Computer Systems Engineering.

'Headquarters and Laboratories at Gathersburg. MD. unless otherwise noted. mailing address Wasnington. DC 20234.

'Some divistons within the center are located at Boulder. CO 80303. 
NBS BUILDING SCIENCE SERIES 154

Wind Loading

and Strength of Cladding Glass

D. A. Reed

E. Simiu

Center for Building Technology

National Engineering Laboratory

National Bureau of Standards

Washington, DC 20234

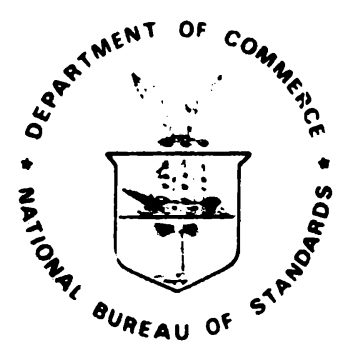

U.S. DLPARTMENT OF COMMERCE, Malcolm Baldrige, Secretary

NATIONAL BUREAU OF STANDARDS, Ernest Ambler, Director

lssued May 1983 
Library of Congress Catalog Card Number: 83-600515

National Bureau of Standards Building Science Series 154

Natl. Bur. Stand. (U.S.), Bldg. Sci. Ser. 154, 49 pages (May 1983)

CODEN: BSSNBV

For sele by the Stuperintendent of Documents, U.S. Covernment Printing Office, Washington, DC 20402 Price N.00

(Add 25 percent for other then U.S. melling) 


\begin{abstract}
A procedure for investigating glass cladding behavior under arbitrary loads, including fluctuating wind loads, is presented. The procedure accounts for the fact that internal stresses are nonlinear functions of the external loads, that initial glass strengths are random functions of position and direction, and that glass strength undergoes degradation under the action of external loads in accordance with basic fracture mechanics laws. Numerical exampies are presented, and corresponding probability distribution curves are calculated, Indicating the probability of fallure of a specified panel subjected to fluctuating wind loads and to 1 -minute constant loads. These curves are used to 1llustrate a method for assessing current glass cladding design procedures. For the case considered in the paper, it was found that transformation of the peak wind load averaged over $1-2$ seconds into an equivalent 1-minute load appears to underestimate the probability of fallure of glass cladding. The work reported in the paper is part of an ongoing window cladding research program being conducted at the National Bureau of Standards.

Key words: aerodynamics; bulldings; deformation; englneering mechanics; fallure; glass; loads (forces); probability theory.
\end{abstract}




\section{ACKNOWLEDGMENTS}

Cover photo: Guaranty Bank Building, Corpus Christi, Texas, following Hurricane Celia, August 3, 1980. View is of the east face of the building. The photograph was graciously supplied by $\mathrm{Dr}$. Joseph F. Minor, Director of the Institute for Disaster Research, Texas Tech University, Lubbock, Texas, 79409.

The writers are indebted to S. M. Wiederhorn, E. R. Fuller, and S. W. Freiman of the Center for Materials Science, NBS, J. E. Minor of Texas Tech

University, and W. A. Dalgliesh of the National Research Council of Canada for useful exchange and advice. 
TABLE OF CONTENTS

$\underline{\text { Page }}$

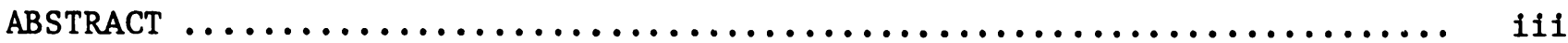

ACKNOWLEDGMENTS $\ldots \ldots \ldots \ldots \ldots \ldots \ldots \ldots \ldots \ldots \ldots \ldots \ldots \ldots \ldots \ldots \ldots \ldots \ldots$ iv

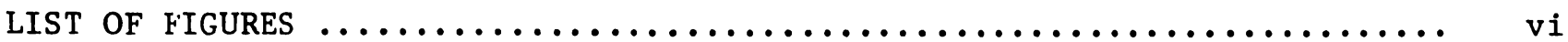

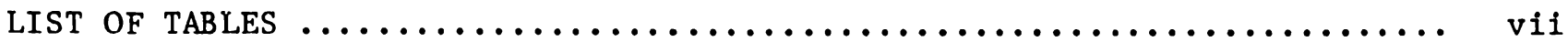

1. INTRODUCTION $\ldots \ldots \ldots \ldots \ldots \ldots \ldots \ldots \ldots \ldots \ldots \ldots \ldots \ldots \ldots \ldots \ldots \ldots \ldots \ldots$

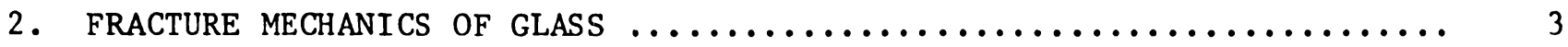

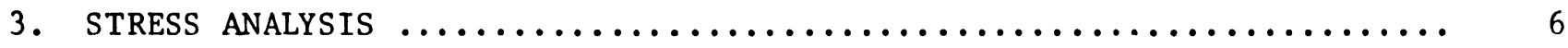

4. WIND LOADING $\ldots \ldots \ldots \ldots \ldots \ldots \ldots \ldots \ldots \ldots \ldots \ldots \ldots \ldots \ldots \ldots \ldots \ldots \ldots$

5. PROPOSED PROCEDURE FOR INVESTIGATING GLASS BEHAVIOR ............ 8

6. INPUT DATA FOR NUMERICAL CALCULATIONS $\ldots \ldots \ldots \ldots \ldots \ldots \ldots \ldots \ldots \ldots \ldots \ldots$

7. PROBABIt.ITIES OF GLASS FAILURE $\ldots \ldots \ldots \ldots \ldots \ldots \ldots \ldots \ldots \ldots \ldots \ldots \ldots \ldots \ldots$

8. ASSESSMENT OF CURRENT PROCEDURES FOR DESIGNING GLASS CIAADDING ....... 12

9. ConCLUSIONS $\ldots \ldots \ldots \ldots \ldots \ldots \ldots \ldots \ldots \ldots \ldots \ldots \ldots \ldots \ldots \ldots \ldots \ldots \ldots \ldots \ldots$

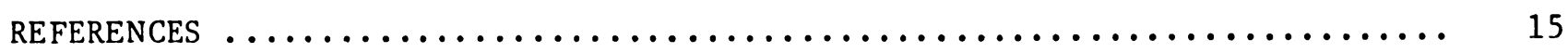

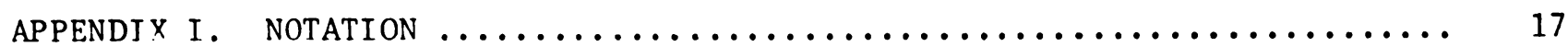

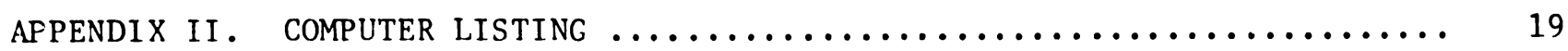




\section{LIST OF FIGURES}

Page

$F i_{\text {t, }}$ :re 1. Crack velocity vs. $\ln \left(\mathrm{K}_{\mathrm{I}}\right)$ for soda-lime silica glass [23] ... 36

Figure 2. Center and corner maximum principal stresses for a square plate 37

Figure 3. Schematic representation of angles $\alpha_{k}=k \Delta \alpha \ldots \ldots \ldots \ldots \ldots$

Figure 4. Cumulative distribution function for $p(t) \ldots \ldots \ldots \ldots \ldots$

Figure 5. Evolution of strength and stresses with time for breaking panel 40

Figure 6. Cumulative distribution function for $p 60 \ldots \ldots \ldots \ldots \ldots \ldots \ldots$ 


\section{LIST OF TABLES}

Page

Table 1. Estimated Probabilities of Fallure Based on Stress Time History, and on '-Minute Loads Estimated in Accordance with

References 12 and 3 . Units of pressure $=$ psf $\ldots \ldots \ldots \ldots \ldots \ldots .35$ 


\section{INTRODUCTION}

The improvement of design procedures for cladding glass subjected to wind loads has been the focus of a considerable amount of research in recent years. In 1979, Pittsburgh Plate Glass (PPG) published revised design charts [2] based upon nonlinear stress analyses used in confunction with elementary statistical methods. In a number of instances, these charts differ from those issued by other manufacturers, notably LOF [8], and exhibit internal inconsistencies as well. For example, according to the PPG charts, a $3.67 \mathrm{ft} \times 18.33 \mathrm{ft}(1.12 \mathrm{~m}$ $x 5.60 \mathrm{~m})$ glass panel with a thickness of $12.7 \mathrm{~mm}$ supported on four sides deflects $11.9 \mathrm{~mm}$ under a load of 100 psf $(4790 \mathrm{~Pa}))$; for a panel with a span of $1.12 \mathrm{~m}$, with the same thickness and under the same load but supported on two sides, the deflection as obtained from the PPG charts is only $9.1 \mathrm{~mm}$, rather than being equal to or in excess of $11.9 \mathrm{~mm}$. Inconsistencies with respect to design loads exist as well. As an example, for a $1 / 8 \mathrm{in}$ ( $3 \mathrm{~mm}$ ) thick annealed float glass panel supported on four sides the PPG charts specify a 15 psf $(719 \mathrm{~Pa})$ one-minute load if the dimensions of the panel are $2.83 \mathrm{ft} x$ $7.07 \mathrm{ft}(0.865 \mathrm{~m} \times 2.15 \mathrm{~m})$, and the same - rather than a larger - ore-minute load if the dimensions are $2.24 \mathrm{ft} \times 6.70 \mathrm{ft}(0.68 \mathrm{~m} \times 2.04 \mathrm{~m})$. Inconsistencies such as these, and discrepancies with respect to other manufacturers' charts [8], suggest that the development of an improved theoretical framework for the design of glass cladding is a necessary task.

An important step toward such an improvement was proposed in 1980 by Beason [2]. Reference 2 combined nonlinear stress analysis with the cldssic Weibull theory to estimate the probability of fallure of a glass panel subjected to a specified load, given the parameters of the Weibull distribution of the glass strength. Conversely, the procedure of reference 2 can be applied to estimate these parameters from information cbtained by loading glass panels up to the fallure point.

The procedure of reference 2 requires the transformation of the stresses induced by actual, time-dependent loads into nominal stresses corresponding to a l-minute constant load. It is suggested in reference 2 that the transformation be carried out by using the following relationship:

$$
\sigma_{60}(M)=\left[\frac{\int_{0}^{t_{f}} \sigma^{n}(M, t) d t}{60}\right]^{1 / n}
$$

where $\sigma_{60}(M)=$ equivalent one-minute stress at point $M, \sigma(M, t)=$ stress induced by actual load at point $M$ and time $t, t_{f}=$ duration of loading or time to fallure in seconds, whichever is smaller, and $n=$ material constant. However, the time to failure $t_{f}$ in equation $l$ is unknown for panels that would fall under wind loads. To the extent that an arbitrary value for $t_{f}$ is used in equation 1 , and that this vaiue could differ by as much as one or even two more orders of magnitude from actual values, significant errors would be introduced in estimating $\sigma_{60}(M)$. Note also that if equation 1 were used, it would be necessary to evaluate the integral at each point $M$, since the systen is nonlinear ( $1 . e$, , in general $\sigma(M, t)$ is not proportional to the wind loading at time $t, p(t))$. 
On account of the difficulty--or impossibility--of specifying $t_{f}$, and of estimating the integrals in equation 1 , to the writers' knowledge, no previous attempts have been made to study the behavior of glass cladding subjected to fluctuating wind loads. Instead, previous research has focused on the study of the behavior of glass cladding subjected to nominal 1-minute loads purported to be representative of fluctuating loads.

The purpose of this paper is to present a procedure for studying the behavior of glass under arbitrary time-dependent loads, including fluctuating wind loads. Like reference 2, the present procedure is based on a nonlinear analysis of stresises that develop under the action of the external loads, and on a Weibull probabilistic nodel for the strength of glass. However, unlike reference 2 , the procedure presented here incorporates phenomenological models describing the fracture mechanisms of glass developed in the last decade by Wiederhorn and other workers (e.g., see references $5,25,26$ ), as well as information on the fluctuating character of the wind loads. No a prior 1 assumptions are needed with regard to the time to failure, $t_{f}$, which is one of the outputs of the procedure. As in reference 2, it is assumed that temperature and humidity effects can be neglected. Additional outputs include the location and direction of the failure inftiation crack, and the amount of strength degradation due to the action of the fluctuating wind load.

To provide a background for the development of the proposed procedure, basic elements of the fracture mechanics of glass will be briefly summarized. A method for obtaining time-dependent stresses from time-dependent loads, which utilizes a co:aputer program developed at Texas Tech University, will be described. A brief section will be devoted to the subject of time-dependent wind loading on cladding glass. The proposed procedure for investigating glass behavior under arbitrary loads will then be presented. The procedure will be applied to obtain estimates of probabilities of failure of a glass panel under fluctuating wind loads and under one-minute constant loads. Suci estimates will then be used to illustrate a method for assessing current practices for the design of glass cladding subjected to wind loads. 


\section{FRACTURE MECHANICS OF GLASS}

The basic criterion for fracture is derived from the Griffith equilibrium expression, which can be written as

$$
\mathrm{K}_{\mathrm{I}}=\mathrm{K}_{\mathrm{IC}}
$$

where $K_{I}=$ stress intensity factor, and $K_{I C}=$ critical value of $K_{I}$. If equation 2 holds, the system reaches the state of instabllity wherein the rate of crack growth becomes for practical purposes infinite [5, 7] and fallure occurs. $\mathrm{K}_{\mathrm{IC}}$ is a property of the material and is determined experimentally. The stress intensity factor, $K_{I}$, is proportional to the actual stresses in the material in the presence of cracks causing stress concentrations. $K_{I}$ can be expressed as follows [5, 7]:

$$
K_{I}(c)=: \sigma(t) \sqrt{c(t)}
$$

w'ie re

$$
\begin{aligned}
& \mathrm{Y}=\text { geometric shape factor } \\
& \sigma=\begin{array}{l}
\text { nominal stress (i.e., stress calculated by assuming the absence of } \\
\text { cracks) }
\end{array} \\
& c=\text { crack length } \\
& t=\text { time }
\end{aligned}
$$

The geometric shape factor. $Y$, is assumed to be constant; this is equivalent to assuming that the crack geometry does not change and can be characterized by one dimension, c. According to experiments reported in references 5 and 22-26, the following relationship holds for the rate of subcritical crack growth (figure 1):

$$
\frac{d c}{d t}=A_{I}^{n}(t)
$$

The parameters $A$ and $n$ depend upon ambient humidity and temperature and are obtained experimentally. Equation 4 expresses quantitatively the fact that the cracks of an element of glass subjected to stress for some length of time will grow - albeit not catastrophically - provided that the stress is contained within a certain range. This phenomenon is referred to as static or dynamic fatigue according to whether the stress is constant or time-dependent.

It follows from equations 2 and 3 that the strength of glass, S, 1.e., the value of the nominal stress at which fallure occurs, 1s:

$$
S(t)=\frac{K_{I C}}{Y \sqrt{C(t)}}
$$


If $K_{I}$ and $c$ are eliminated from equations 3,4 , and 5 and the notation $S(0)=S_{1}$ is used ( $S_{1}=$ initial strength), the following relationship is obtalned:

$$
S(t)=\left[S_{1}^{n-2}-\frac{1}{B} \int_{0}^{t} \sigma^{n}(\tau) d \tau\right]^{\frac{1}{n-2}}
$$

where $1 / B=(n-2) A Y^{2} K_{I C}^{n-2} / 2$ [5]. It follows from the definition of $S(t)$ that fallure occurs if

$$
\sigma(t) \geq S(t)
$$

In the calculations presented in this paper it 18 assumed that the variability of $A$ and $n$ in equation 4 is small and that its effect upon the results being sought can be neglected. As far as the variability of $B$ is concerned, the following comment is in order. Because $B$ is a function of $Y$, which in turn depends upon the flaw shape, its variability is difficult--if at all possible-to ascertain. If a deterministic value of $B$ is assumed, based on a conventional value of $Y$, it is possible by using equation 6 to obtain values of $S_{1}$ from experiments in which $n, A, K_{I c}, \sigma(t)$ are known, and the time to fallure, $t_{f}$, and the strength, $S\left(t_{f}\right)$, are measured. The empirical probability distributions of the initial strength estimated from the values $s_{1}$ so obtained automatically reflect the actual shapes of the flaws.

The Inftial strength $S_{1}$ of an element with area, a, experiencing a uniform, direction-indepindent state of tensile stress throughout one of its outer faces can be described probabilistically by a Welbull distribution [21], 1.e.,

$$
P\left(s_{1}, a\right)=1-\exp \left\{-\left(\frac{s_{i}}{s_{0}(a)}\right)^{m}\right\} \quad \text { for } m \geq 1
$$

where $P\left(s_{1}, a\right)=$ probability that the random variable $S_{1}<s_{1}, S_{0}(a)=$ scale parameter (characteristic strength), and $m=$ shape (tail length) parameter.

The scale parameters, $S_{0}(a)$ and $S_{0}\left(a_{1}\right)$, of two elements with areas a and $a_{1}$, respectively, each experiencing uniform direction-independent states of tensile stress throughout one of its outer faces, can be written as [6]:

$$
s_{0}(a)=s_{0}\left(a_{1}\right)\left(\frac{a_{1}}{a}\right)^{\frac{1}{m}}
$$

This relation reflects the dependence of strength distribution upon the distribution of flaw lengths. The larger the area of the panel, the larger will be the number of $f$ laws and, therefore, the larger the probability that the area will contain a severe flaw to which, by virtue of equation 5 , there corresponds a relatively low inftial strength.

Consider now an alement of glass with uniform but direction-dependent stresses throughout one of 1 ts outer faces. In this case, shear stresses are present, 
in addition to normal stresses. The effect of the normal stresses is by far the strongest, however, as far as crack propagation is concerned [7, p. 52]. Therefore it may be assumed to a first approximation--as is done in reference 2-- that the effects of the shear SLiesses can be rieglected. In the case of the element now being considered fallure will not necessarily be initiated by a flaw normal tu the maximum principal stress - Indeed, 1t may well happen that all such flaws are relatively small. Nelther will fallure be necessarily initiated by the largest flaw within the element, since that flaw may well be perpendicular to a relatively low normal stress. Rather, faflure will be initiated by the largest of the flaws oriented along some ilrection, $\alpha_{f}$, such that

$$
\sigma_{n}\left(t, \alpha_{f}\right)>\frac{K_{I C}}{y \sqrt{c_{\max }\left(t, \alpha_{f}\right)}}
$$

where $\sigma_{n}\left(t, \alpha_{f}\right)=$ normal stress perpendicular to direction $\alpha_{f}$ (equations 5 and 7$)$ and $c_{\max }\left(t, \alpha_{f}\right)=$ length of largest flaw oriented along direction $\alpha_{f}$.

Under the assumption that the distribution of flaw orientation is uniform [2, p. 84], equation 9 can be applied to the case of an element subjected to uniform but direction-dependent state of stress as follows. The probability of occurrence within a certain ar:a of flaws with crack iength dimension less than $c$ and having orientation angles $\alpha_{1}<\alpha<\alpha_{2}$ is equal to $\left(\alpha_{2}-\alpha_{1}\right)$ times the probability of occurrence within an area of flaws with dimension less than $c$ and having any orientation $0<\alpha<2 \pi$. The following relation is therefore consistent with equation 9 lor any elemental circular area:

$$
\mathrm{S}_{0}\left(\alpha_{1}<\alpha<\alpha_{2}\right)=\mathrm{S}_{0}(0<\alpha<2 \pi)\left(\frac{\pi}{\alpha_{2}-\alpha_{1}}\right)^{\frac{1}{m}}
$$




\section{STRESS ANALYSIS}

Equations 6 and 7 cleariy show that to investigate the behavior of glass, information is required on the time history of the stresses induced in the glass by the external loads.

The out-of-plane deflections of glass plates subjected to lateral loads can be large relative to the thickness of the plate. The plate develops substantial mid-plane membrane stresses in this condition, and the von Kárman equations $[18,20]$ must be used to account for this effect. Based on these equations, Vallabhan and Jang [19] have developed a program that uses the finite difference method to determine the deflections and stresses in uniformly loaded simply-supported thin glass plates having boundary conditions allowing for in-plane movement. With the permission of the Institute for Disaster Research, Texas Tech University, this program was employed in the present study to determine the stresses at various locations on the plate. The results from the program were non-dimensionalized as follows [9]

$$
\begin{aligned}
& L F=p b^{4} / D h \\
& S F=\sigma b^{2} h / D
\end{aligned}
$$

where $L F$ and $S F=1$ oading and stress factors, respectively, $p=$ uniform pressure loading, $\sigma=$ corresponding stress, $b=$ smaller side of rectangular plate, $D=$ flexural rigidity, defined by

$$
D=\frac{E h^{3}}{12\left(1-v^{2}\right)}
$$

$\mathrm{E}=$ modulus of elasticity, $v=$ Poisson's ratio, and $\mathrm{h}=$ thickness of plate.

For a square plate, the relationship between SF and LF for various locations 1s shown in flgure 2. Note that the relationship is closer to being linear for the corner than for the center stresses.

Relationships for each location on the plate from the grid used for the finite difference analysis were determined and represented analytically in terms of piece-wise linear curves. On the basis of such relationships, given a timedependent loading, the plate dimensions, and the material properties, the principal stresses and normal stresses corresponding to various directions can be calculated as functions of time. 


\section{WIND LOADING}

Wind loading on cladding has a fluctuating character. Because the dimensions of cladding panels are relatively small (on the order of a few meters at most) it is acceptable to assume that the fluctuating loads acting over the area of the panel are uniformly distributed at any one initant and proportional to the pressures at the panel center.

The wind loads depend upon the local extreme wind climate [16, 17], the features of the oncoming air flow (which are in turn dependent upon the roughness of the surrounding terrain and the possible presence of neighboring buildings), and the aerodynamic characteristics of the building in question. These characteristics differ from point to point on the building facades and are, in addition, dependent upon wind direction.

Wind loading time historles are obtained principally from wind tunnel tests. Any given loading time history can be analyzed to determine its statistical characteristics; e.g., mean, standard deviation and peak. Models of the loading can be obtained in the frequency domain (using a spectral approach, for example, see reference 17), or in the time domain, e.g., using a Box-Jenkins approach [14]. Knowledge of these models in turn allows the numerical simuiation of loading time histories that correspond to various reference wind speeds. In the particular case of a mean wind speed normal to a bullding $f$ ace and in the absence of neighboring bulldings which significantly alter the oncoming flow field, at a point $Q$ near the center of the bullding face the pressures may be written approximately as

$$
\begin{aligned}
& \bar{p}(Q)=\frac{1}{2} \rho C_{p}(Q) \bar{v}^{2}(z) \\
& p^{\prime}(Q, t)=\rho C_{p}(Q) \bar{v}(z) v^{\prime}(z, t)
\end{aligned}
$$

where $\bar{p}$ and $p^{-}=$mean and fluctuating pressure, respectively, $\rho=$ air density, $C_{p}(Q)=$ pressure coefficient at point $Q, z=$ elevation of point $Q, \bar{v}(z)=$ mean wind speed, at elevation $z$ and $v^{\prime}(z, t)=$ longitudinal fluctuating component of wind speed. The fluctuating pressures can be simulated from spectral information or $v^{-}(z, t)[17]$. 


\section{PROPOSED PROCEDURE FOR INVESTIGATING GLASS BEHAVIOR}

Earlier in this paper it was noted that a glass panel will not necessarily fail at the point of maximum stress or of minimam strength. Rather, fallure will occur where the relationship between stress and strength is such that equation 7 18 satisfied, where $S(t) 18$ given by equation 6 , and $S_{1}$ is described probabilistically by equation 8 (recall that the effects of area and of stress directionality are included in the procedure through equations 9 and 11).

With this background it 18 now possible to describe the proposed procedure for investigating glass behavior. The procedure entalls the following steps:

1. For any given mean wind speed and direction generate the time history of the wind loading for the glass cladding panel of concern by Monte Carlo simulation as outilned in the section "Wind Loading."

2. Using the procedure outlined in the section "Stress Analysis" obtain from the time history of the wind loading the time histories of the stresses normal to the directions $a_{k}=\frac{k \pi}{2 r},(k=1,2, \ldots r)$ at the center, $M_{j}$, of each of the elements into which the panel is divided for numerical computation purposes.

3. From equations 8 and 9 generate by Monte Carlo simulation Initial strengths $S_{1}\left(M_{j}, \alpha_{k}\right)$, where $\alpha_{k}=k \Delta \alpha(k=0,1,2, \ldots n)$ - see f1gure 3.

4. Evaluate numerically the expression

$s\left(M_{j}, \alpha_{k}, t\right)=\left\{s_{1}^{n-2}\left(M_{j}, \alpha_{k}\right)-\frac{1}{B} \int_{0}^{t}\left[\sigma^{n}\left(M_{j}, \alpha_{k}, \tau\right)\right] d \tau\right\}^{\frac{1}{n-2}}$

for $a l 1 ~ j$ and $k$ and $t=m \Delta t$, where $\Delta t=1$ incremental time used in numerical computations, and $m=1,2, \ldots$.

5. Computation is stopped if for at any set $j, k$, $\sigma\left(M_{j}, \alpha_{k}, m \Delta t\right) \geq s\left(M_{j}, \alpha_{k}, m \Delta t\right)$.

At that point, fallure of the general panel has occurred. 


\section{INPUT DATA FOR NUMERICAL CALCULATIONS}

Numerical examples were carried out for the case of annealed float glass panels simply supported on four sides with dimensions $4 \mathrm{ft} \times 4 \mathrm{ft} \times 1 / 8$ in $(1.2 \mathrm{~m} \times 1.2 \mathrm{~m} \times 3 \mathrm{~mm})$. The following parameters were used: $\mathrm{S}_{0}\left(a_{1}=1 \mathrm{~m}^{2}\right)$ $=35.2 \mathrm{MPa}[4], \mathrm{m}=6[4], \mathrm{A}=1.08(\mathrm{MPa})^{-n} \mathrm{~m}^{1-\overline{2}} \mathrm{sec}^{-1}[23], \mathrm{n}=19.69$ [23], $\mathrm{K}_{\mathrm{I}}=0.75 \mathrm{MPa}[23], \nu=0.22[2], E=0.0689 \mathrm{MPa}[2]$. The values $\mathrm{A}$ and $\mathrm{n}$ correspond to 50 percent humldity and $20^{\circ} \mathrm{C}$ temperature (see figure 1). It was assumed that the geometric shape factor $\mathrm{Y}=1.12$ [see reference 10 for detalls]. It was further assumed that the glass panel is located near the center of a building facade at an elevation of $z=150 \mathrm{ft}(46 \mathrm{~m})$, that it is subjected to winds normal to the bullding $f$ ace, that the building is located in open terrain, and that $C_{p}=1.0$ in equations 14 and 15 .

For any given mean wind speed, $\nabla$, the corresponding mean wind pressure was obtained by using equation 14. The fluctuating wind pressures were g, 2 nerated by numerical simulation using equation 15 and the following expression for the spectrum of the longitudinal velocity fluctuations $v^{\prime},[17]$ :

$$
\frac{\tilde{n}}{s_{v}(\tilde{n})} u_{\star}^{2}=\frac{200 f}{(1+50 f)^{5 / 3}}
$$

where $u_{*}=\bar{v}(z) /\left[2.5 \ln \left(z / z_{0}\right)\right], \quad \tilde{n}=$ frequency, $f=\tilde{n z} / \overline{v(z)}, z=$ elevation of panel in meters, and the roughness lingth corresponding to open terrain $z_{0}=$ $0.07 \mathrm{~m} \mathrm{[17].}$ 


\section{PROBABILITIES OF GLASS FAILURE}

Failure of Glass Cladding Under Fluctuating Wind Loads. Consider the wind load, $p_{1}(t)$, corresponding to a mean wind speed, $v(z)$. The subscript, 1, Indicates that $p_{1}(t)$ is the 1 -th realization of the specified stochastic process. Let $x_{p}, y_{p}$ be the coordinates of the centers of the elements into which the glass panel is divided. The size of these elements is sufficiently small so that the variation of the stresses over each element is insignificant for practical purposes. Let $\alpha_{r}$ be the directions, perpendicular to the normal stresses. being considered at each point. Obtain the stresses $\sigma_{1}\left(x_{p}, y_{q}, \alpha_{r}, t\right)$ corresponding to $p_{1}(t)$ for all values $p, q, r$. Assume that the number of panels (the sample size) is $L$. Simulate initial strengths $s_{o l}\left(x_{p}, y_{q}, \alpha_{r}\right)$ for one given set of values $p, q, r$ for all the panels of the sample $(l=1,2, \ldots L)$. Rank order these strengths beginning with the smallest. Denote this smallest value by $s_{o l}\left(x_{p}, y_{q}, \alpha_{r}\right)$. Compare $\sigma_{1}\left(x_{p}, y_{q}, \alpha_{r}, t\right)$ to $s_{1}(t)$ by using equation 6. If $\sigma_{1}<s_{1}$ for every $t$, then no panel will break at point $x_{p}$, $y_{q}$ in the direction of $\alpha_{r}$. However, if $\sigma_{i}>s_{1}$ for some $t$, the parel for which the initial strength at $x_{p}, y_{g}, \alpha_{r}$ is $S_{o l}$ will break. One breakage is recorded, and the panel concerned is eliminated from further consideration. If $\sigma_{1}>s_{2}$, where $\mathrm{S}_{2}$ is derived from the second smallest initial strength for the given $p, q, r$, then breakage initiated at $x_{p}, y_{q}, \alpha_{r}$ will occur. Repeat the comparison until $\sigma_{i}<S_{N}$. The number of fallures initiated at $x_{p}, y_{q}, \alpha_{r}$ will then be $\tilde{N}=\mathrm{N}-1$, and the corresponding panels are eliminated from further consideration. Repeat the procedure for all values, $p, q, r$. The probability of failure under load $p_{i}(t)$ is $P\left[\right.$ fallure $\left.\mid p_{i}(t)\right]=\Sigma(\tilde{N} / L)_{i}$. Repeat the the procedure for different realizations of the pressure. The probability of failure under load $p(t)$ is $P[f a i l u r e \mid p(t)]=\sum_{j}^{G}$ Prob. [failure $\left.\mid p_{i}(t)\right] / G$, where the summation is over the number of realizations, G, being considered.

A cumulative distribution function $P[f$ ailure $\mid p(t)]$ is derived indicating that the strength of the plate is less than required to withstand the load $p(t)$ in $100 \times P[f a f l u r e \mid p(t)]$ percent of the cases. Note that $P[f a 1 l u r e \mid p(t)]$ embodies both the characteristics of the material and the aerodynamic characteristics of the loading under consideration. These two types of characteristics are inseparable owing to the dependence of glass strength upon load time history.

For convenience, the load $p(t)$ may be indexed by 1 ts mean value $\bar{p}$, so that the notation $P\left[\right.$ failure $\mid \bar{p}$ ], or simply $P_{f}(\bar{p})$ may be substituted for $P$ [failure $\mid \mathrm{p}(t)]$. Estimates of points of the cumulative distribution function $\mathrm{P}_{f}(\bar{p})$ estimated for the conditions described in the section "Input Data for Numerical Calculations" are shown in figure 4. These points were obtained for simulated fallure tests carried out on two sets of 1,000 panels, each set being subjected to different realizations of the fluctuating pressure, $p(t)$.

Typical time histories of pressure, stress, and strength at panel points where fallure was found to occur are shown in figure 5. Note the continuous strength 
degradation under icad. In certain instances a storm can cause significant strength degradation ithout causing fallure. The weakened panel could then break under the action of subsequent, less intense storms, should such storms occur during its 11 fetime.

Failure of Glass Cladding Under 1-Minute Constant Load. Let the normal stress induced by the 1-minute load, $\mathrm{p}_{60}$, and the inftial strength be denoted by $\sigma_{60}(M, \alpha)$ and $S_{1}(M, \alpha)$, respectively, where $M$ and $\alpha$ are the point and the direction under consideration. It is assumed that the 60-second action of $\sigma_{60}$ $(M, \alpha)$ causes fallure. It follows from equation 6 that, with negligible error, the following relation holds:

$$
\sigma_{60}(M, \alpha) \simeq\left(\frac{s_{1}^{n-2}(M, \alpha)}{60 / B}\right)^{1 / n}
$$

The procedure for obtalning $\mathrm{p} 60$ is as follows: Generate initial strengths, $\mathrm{s}_{\mathrm{o} \ell}\left(\mathrm{x}_{\mathrm{p}}, \mathrm{y}_{\mathrm{q}}, \alpha_{\mathrm{r}}\right)$ for $\ell=1,2, \ldots$ L panels. Use equation 19 to solve for $\sigma_{60}$ $(M, \alpha)$ at each $x_{p}, y_{q}, \alpha_{r}$ for panel $\ell$. Calculate the value of $p_{60}$ corresponding to each $0_{60}(M, \alpha)$. Find the minimum $p_{60}$ for panel $\ell$; it represents the lowest 60-second pressure loading for which fallure of panel $\ell$ will occur. Repeat the procedure for $\ell=1,2, \ldots$ L panels. The results obtained can be plotted in the form of a cumulative distribution function P[fallure | F 60], denoted as $P_{f}\left(p_{60}\right)$. Figure 6 shows a cumulative distribution $P_{f}\left(P_{60}\right)$ for the conditions described in the section "Input Data for Numerical Calculations," based results of obtained for a set of 4,000 panels.

Note that according to the PPG charts [2] the 1-minute load, P60, corresponding to a probability of failure of 8 in 1,000 is 23 psf. The corresponding value of $\mathrm{p} 60$ indicated by figure 6 is about 19 psf. 
The purpose of this section is to compare the current design loadings with the present procedure.

Procedure Used in Refs. 12-13. This procedure is based on the assumption that the effect of wind loading is determined solely by the peak load averaged over 1 or 2 seconds that occurs during the storm. It is assumed that the loading on the cladding which is subjected to a fluctuating wind pressure is equivalent to a $1-$ minute constant pressure, $\mathrm{P} 60$, defined as

$$
\underset{p_{60}}{C}=p_{p k}\left(\frac{t p k}{60}\right)^{\frac{1}{n}}
$$

where $p_{p k}=$ peak pressure averaged over the $t i m e, t_{p k}$, that occurs during the storm being considered, and $t_{\mathrm{pk}}=1-2$ seconds. According to this assumption, then, provided that $\mathrm{p}_{\mathrm{pk}}$ is the same, it does not matter whether the mean loading is large and the fluctuations are small or vice-versa. The probability of fallure of a panel subjected to a load, $p(t)$, implicit in reference 12 is thus equal to the probability of fallure of that panel under the action of a 1 -minute load, $\mathrm{p}_{60}$, obtained from $p(t)$ by using the above equation.

Procedure Proposed in Ref. 3. This procedure assumes that the equivalent 1-minute pressure loading is given by

$$
\mathrm{P}_{60}^{\mathrm{D}}=\left\{\frac{\int_{0}^{t} \mathrm{p}^{n}(t) d t}{60}\right\}^{1 / n}
$$

where $t_{s}=$ duration of storm.

Comparison of Design Loadings Based on Various Procedures. The purpose of

\section{D}

this section is to compare the loads $p(t), p_{60}$, and $p_{60}$ corresponding to various probabilities of failure. These loads are obtained from the cumulative distribution functions of figs. 4 and 6 .

To the storm with mean speed $\bar{v}$ these corresponds a mean pressure $\bar{p}$, a

$\mathrm{C}$

1-minute load obtained in accordance with reference $12, \mathrm{P}_{60}$, and a 1-minute load $\mathrm{D}$

obtained in accordance with reference $3, \mathrm{P}_{60}$. For the conditions described in the section "Input Data for Numerical Calculations," the ratios $\mathrm{P}_{60} / \overline{\mathrm{p}}$ and $\mathrm{p}_{60} / \overrightarrow{\mathrm{p}}$ were found to be approximately 1.08 and 1.26 , respectively. Values of $\mathrm{P}_{60}$ and $\mathrm{P}_{60}$ corresponding tc various values $\bar{p}$, and the probabilities of fallure 
$P_{f}(p) \equiv P[$ fallure $\mid p(t)], P_{f}\left(p_{60}^{C}=p_{60}\right)$, and $P_{f}\left(\begin{array}{c}D \\ p_{60}\end{array}=p_{60}\right)$, obta1ned from figs. 4 and 6 , are listed in tabie l. It is seen that, in this instance, the estimates based on the procedure of reference 12 appear to be overly optimistic, i.e., they appear to underestimate the probability of fallure of the panel unier any given storm and, therefore, the probability of fallure of the panel during its lifetime. The probability estimates based on the procedure of reference 3 are somewhat closer to those based on the time history of the stresses. Note that for storms causing rates of fallure of about 8 in a 1,000 the probability estimates based on the stress time history and on the nominal

C D

1-minute loads $\mathrm{P} 60$ and $\mathrm{P} 60$ happen in this case to be relatively close. The respective discrepancies increase considerably in the case of stronger storms. 


\section{CONCLUSIONS}

A procedure for investigating glass cladding behavior under arbitrary loads, including fluctuating wind loads, was presented. The procedure accounts for the fact that internal stresses are nonlinear functions of the external loads, that inftial glass strengths are random functions of position and direction, and that the glass strength undergoes degradation under the action of external loads in accordance with basic fracture mechanics laws that reflect subcritical crack growth. Numerical examples were presented, and corresponding probability distributions were calculated, indicating the probability of failure of a specified panel subjected to fluctuating wind loads and to 1 -minute constant loads. These curves are used to lllustrate a method for assessing current glass cladding design procedures. For the case considered in the paper it was found that procedures based on the transformation of the wind load averaged over 1-2 seconds into an equivalent 1-minute load appear to result in overly optimistic assessments of the probability of fallure of glass cladding under wind loads. The work reported in the paper is part of an ongoing window cladding research program being conducted at the iNational Bureau of Standards. Futire work will consider the effect of fluctuating loads on corner and eave panels, and the effect upon fracture load predictions of the variability of the parameters that control glass behavior under load. 


\section{REFERENCES}

1. American National Standards Institute. "Building Code Requirements for Minimum Design Loads In Bulldings and Other Structures," ANSI A58.1-1972, 1972.

2. Beason, William L., "A Fallure Prediction Model for Window Glass," Institute for Disaster Research, Texas Tech Un1versity, Lubbock, Texas, May 1980 .

3. Dalgliesh, W. A., "Assessment of Wind Loads for Glazing Design," Practical Experiences with Flow-Induced-Vibrations, IAHR - IUTAM Symposium, Karlsruhe, Germany, Sept. 3-6, 1979, Springer-Verlag, pp. 696-708.

4. Fuller, E., Wiederhorn, S. M., Ritter, J. E., and Oates, P. B., "Proof Testing of Ceramics: Part II: Theory," J. Materials Science, Vo1. 15, 1980, pp. 2275-2281.

5. Hertzberg, R. W., Deformation and Fracture Mechanics of Materials, John Wiley and Sons, New York, N.Y., 1976.

6. Johnson, N. L. and Kotz, S., Continuous Univartate Distributions, Vo1. I, John Wiley and Sons, New York, N.Y., 1970.

7. Lawn, B. R. and Wilshaw, T. R., Fracture of Bitttle Solids, Cambridge University Press, Cambridge, England, 1970.

8. L. 0. F. Technical Information - Strength of Glass Under Wind Loads, 805-109, Toledo Oh1o, Jan. 1980.

9. Moore, Donald M., Proposed Method for Determining the Thic'ness of Glass in Solar Collector Panels, JPL 80-34, Jet Propuision Laboraturv, Pasadena, 1980 .

10. Newman, J. C., Jr. and Raju, T. S., "Analysis of Surface Cracks in Finite Plates Under Tension or Bending Loads," NASA Technical Paper 1578, Dec. 1979.

11. Peterka, J. A. and Cermak, J. E., "Wind Pressures on Buildings Probability Densities," J. of the Structural Div., ASCE, Vol. 101, No. ST6, June 1975, pp. 1255-1267.

12. Peterka, J. A. and Cermak, J. E., "Wind Tunnel Study of Atlanta Office Building," Research Report of the Fluid Mechanics and Wind Engineering Program, College of Engineering, Colorado State University, Ft. Collins, C0, November 1978.

13. PPG Glass Thickness Recommendations to Meet Architects Specified 1-Minute Wind Load, Technical Services/Flat Glass Division, PPG Industries, April 23, 1979. 
14. Reed, D. A. and Scanlan, R. H., "ARIMA Representation of Turbulence Spectra and Longtudinal Integral Scales," to be published in Proceedings, U.S. - Japan Cooperative Program in Natural Resources, Tokyo, May 1981.

15. Ritter, J. E., Jr., et al., "Proof Testing of Ceramics: Part I : Experiment," J. Materials Science, 15, 1980, pp. 2282-2295.

16. Simiu, E., Changery, M. E., and Filliben, J. J., Extreme Wind Speeds at 129 Stations in the Contiguous United States, Buflding Sclence Series Report BSS 118, National Bureau of Standards, Washington, DC, March 1979.

17. Simiu, E. and Scanlan, R. H., Wind Effects on Structures: An Introduction to Wind Engineering, John Wiley and Sons, New York, N.Y., 1978.

18. Timoshenko, S. and Woinowsky - Krieger, S., Theory of Plates and She11s, 2nd Edition, McGraw-H111: New York, N.Y., 1968, pp. 415-428.

19. Vallabhan, C. V. G. and Wang B. Y. -T., "Nonlinear Analysis of Rectangular Glass Plates by Finite Difference Method," Institute for Disaster Reserach, Texas Tech University, Lubbock, Texas, June 1981.

20. von Kármán, Th., "Encyklopädie der Mathematischen Wissenchaften, Vol. IV, p. 349, 1910.

21. Weibuli, W., "A Statistical Theory of the Strength of Materials," Ingeniörsvetenskapsaka temiens, Hand1ingar NR 151, Stockholm, 1939.

22. Wiederhorn, S. M., "Influence of Water Vapor on Crack Propagation in Soda-L1me Glass", J. Amer. Ceramic Soclety, 50, 1967, pp. 407-414.

23. Wiederhorn, S. M., "Subcritical Crack Growth in Ceramics," in Fracture Mechanics of Ceramics, Vol. 2, Bradt, R. C., Hasselman, D. P. H., and Lange, F. F., eds., Plenum Publishing Corp, New York, 1974, pp. 613-646.

24. Wiederhorn, S. M., "Strength of Glass - A Fracture Mechanics Approach," Proceedings, Tenth International Congress of Glass, The Ceramics Society of Japan, Kyoto, Japan, July 1974.

25. Wiederhorn, S. M., "Dependence of Lifetime Predictions on the Form of the Crack Propagation Equation," Fracture 1979, Vo1. 3, ICF4, Water1oo, Canada, June 19-24, 1977, pp. 893-901.

26. Wiederhorn, S. M., and Ritter, J. E., Jr., "Application of Fracture Mechanics Concepts to Structural lechanics," Fracture Mechanics Applied to Brittle Materials, ASTM STP 678, Freiman, S. W., eds. ASTM, 1979, pp. 202-214. 
APPENDIX I - NOTATION

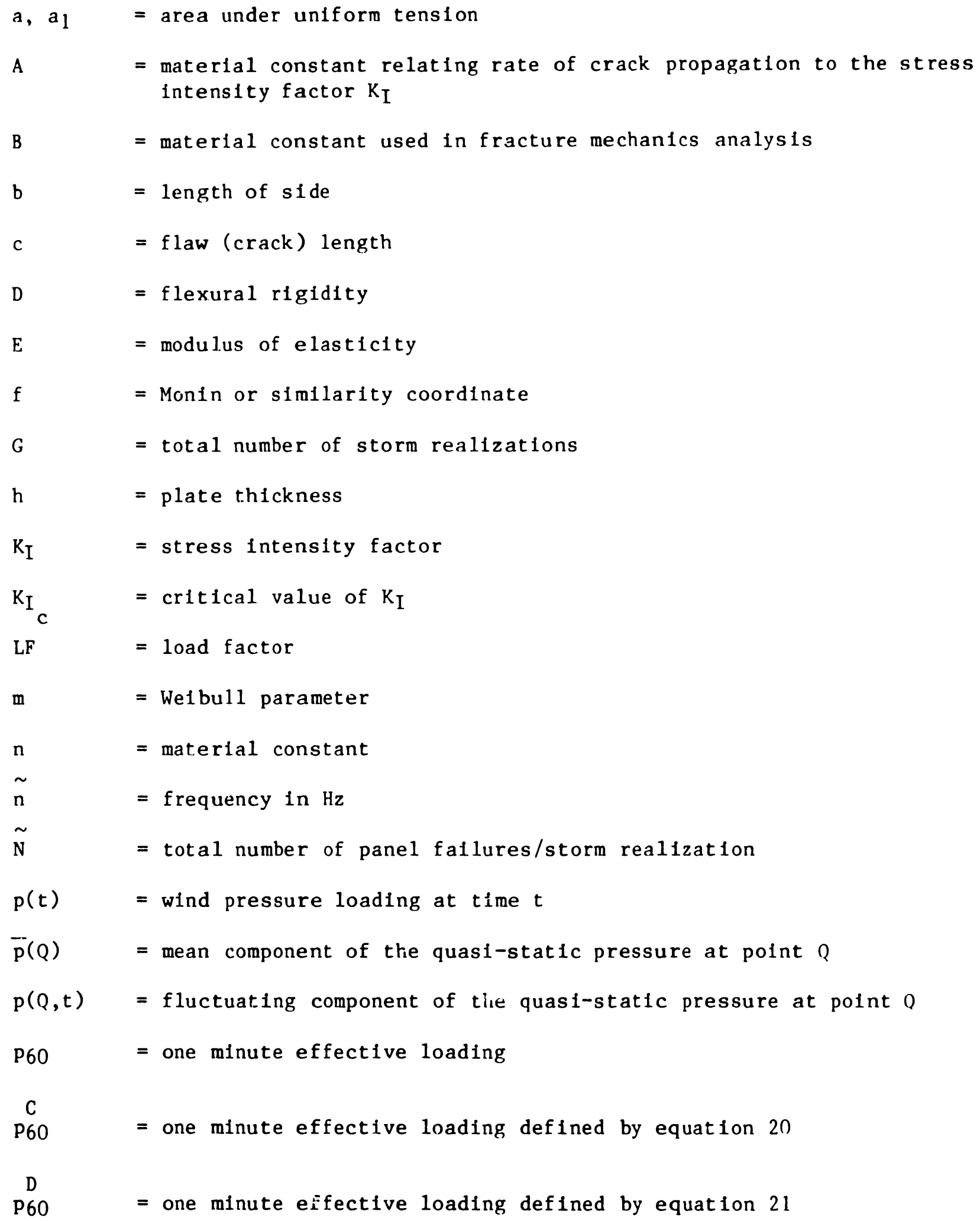




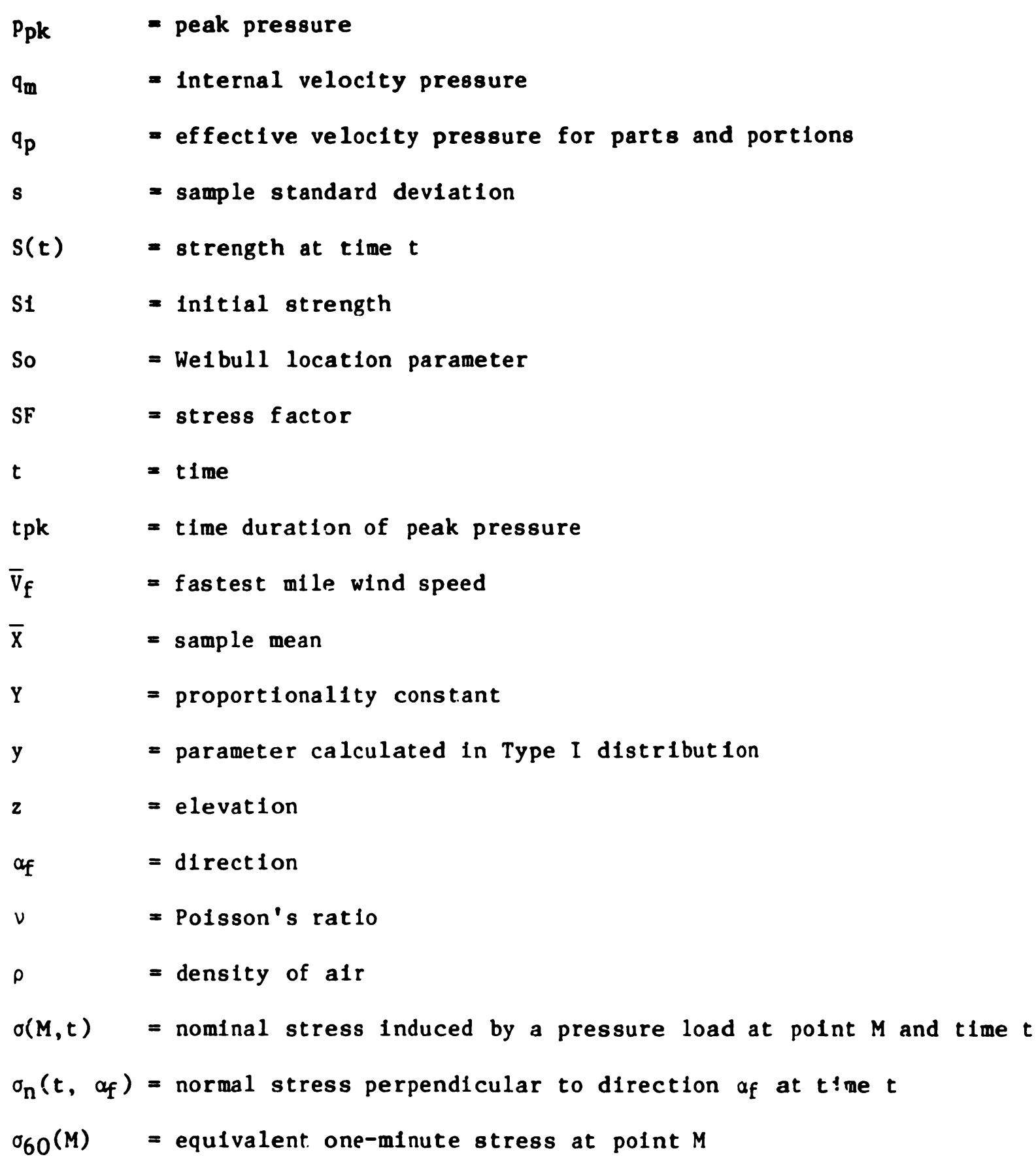


APPENDIX II. COMPIJTER LISTING 


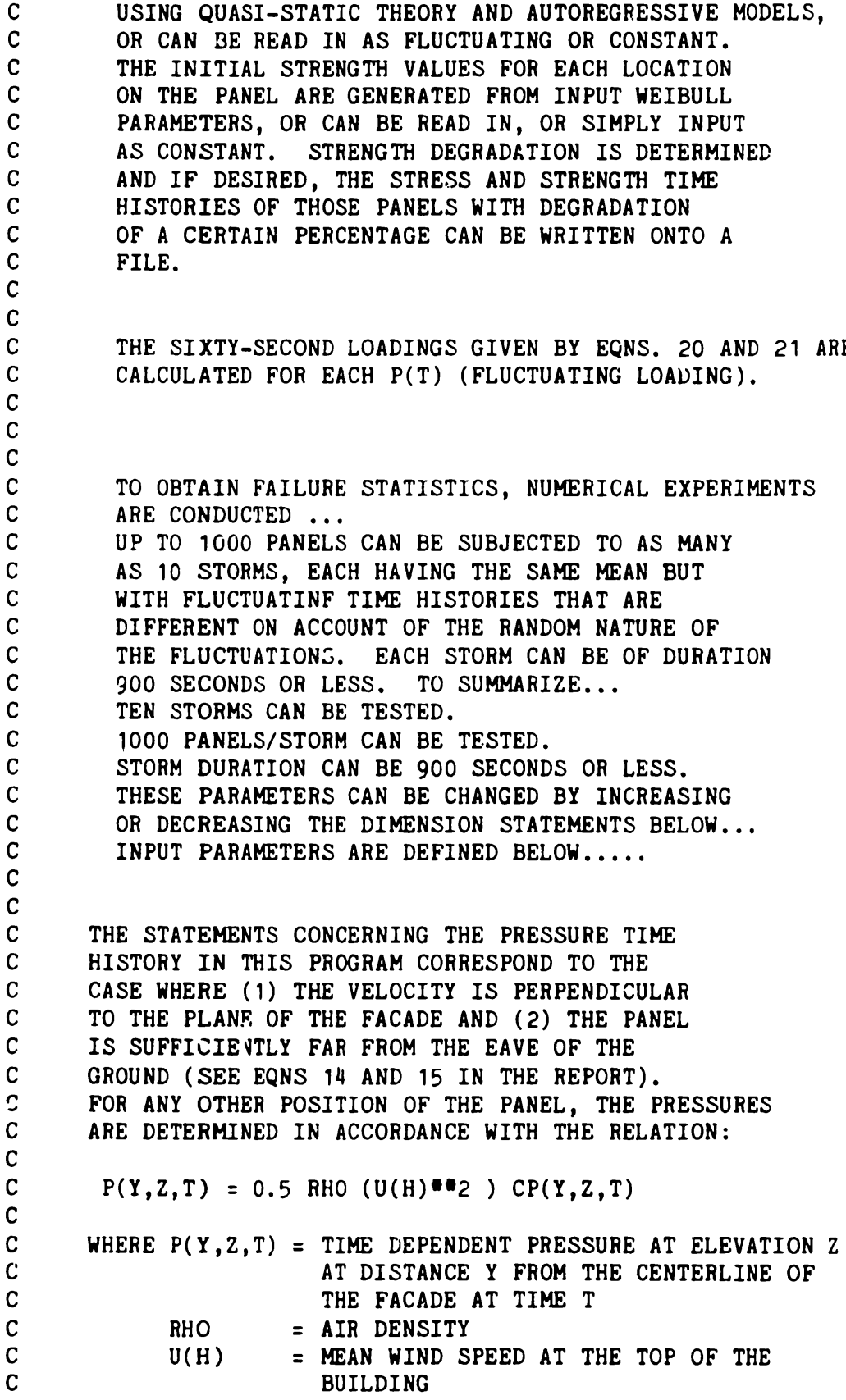

THE STATEMENTS CONCERNING THE PRESSURE TIME HISTORY IN THIS PROGRAM CORRESPOND TO THE CASE WHERE (1) THE VELOCITY IS PERPENDICULAR TO THE PLANF OF THE FACADE AND (2) THE PANEL IS SUFFICIE VTLY FAR FROM THE EAVE OF THE GROUND (SEE EQNS 14 AND 15 IN THE REPORT). FOR ANY OTHER POSITION OF THE PANEL, THE PRESSURES ARE DETERMINED IN ACCORDANCE WITH THE RELATION: 


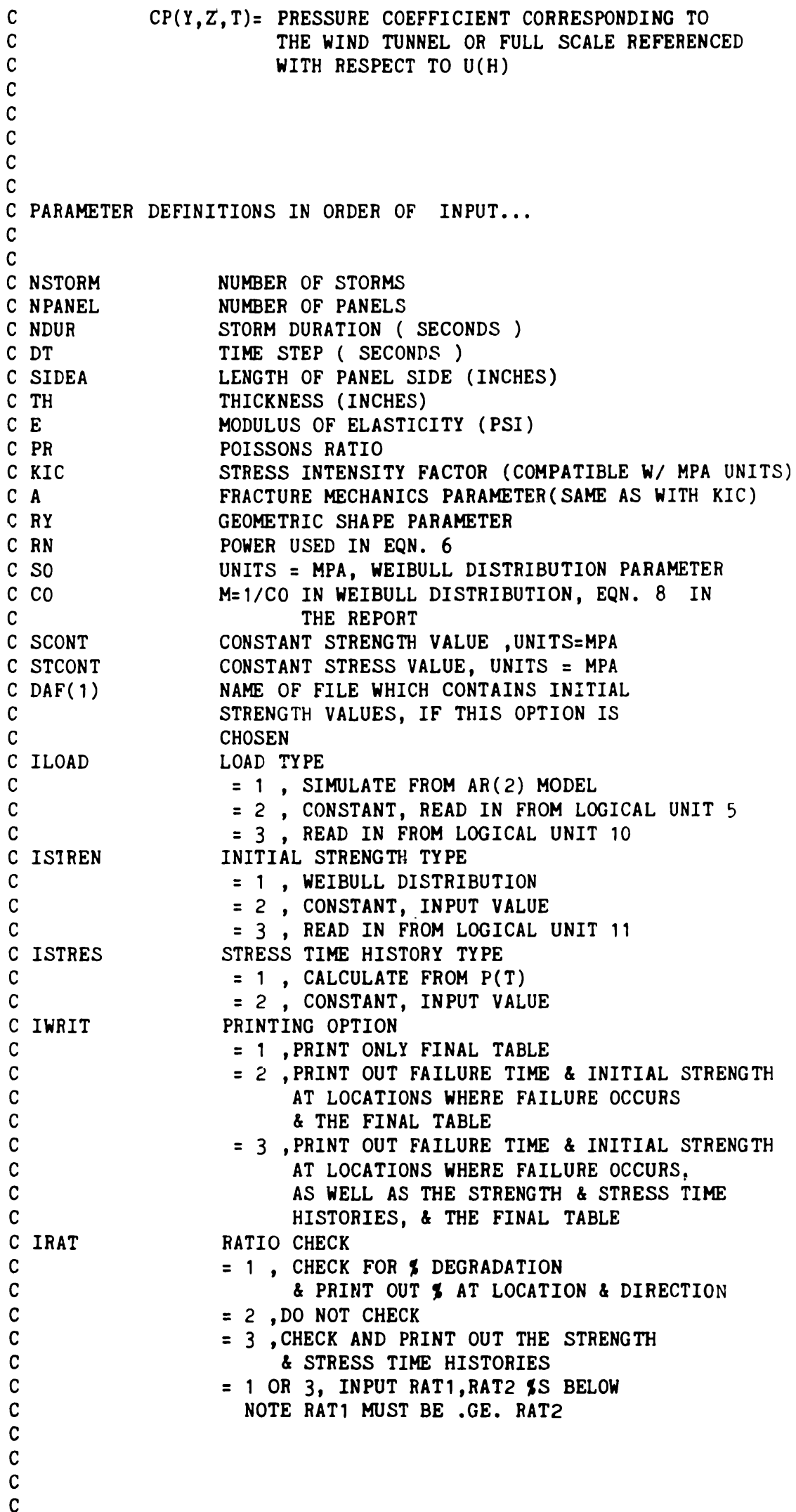

DOUBLE PRECISION DSEED, TERM1, TERM2, RDIFF, RDIR, RATIO, SLOPE DOUBLE PRECISION A1(1000),A2(6), S(900),AI $(6,1000), \operatorname{RSIG}(36,6)$ REAL IT, PV (10), F( 1000), PMEAN, PM(10), NFAIL2(2!6), FMAX, 


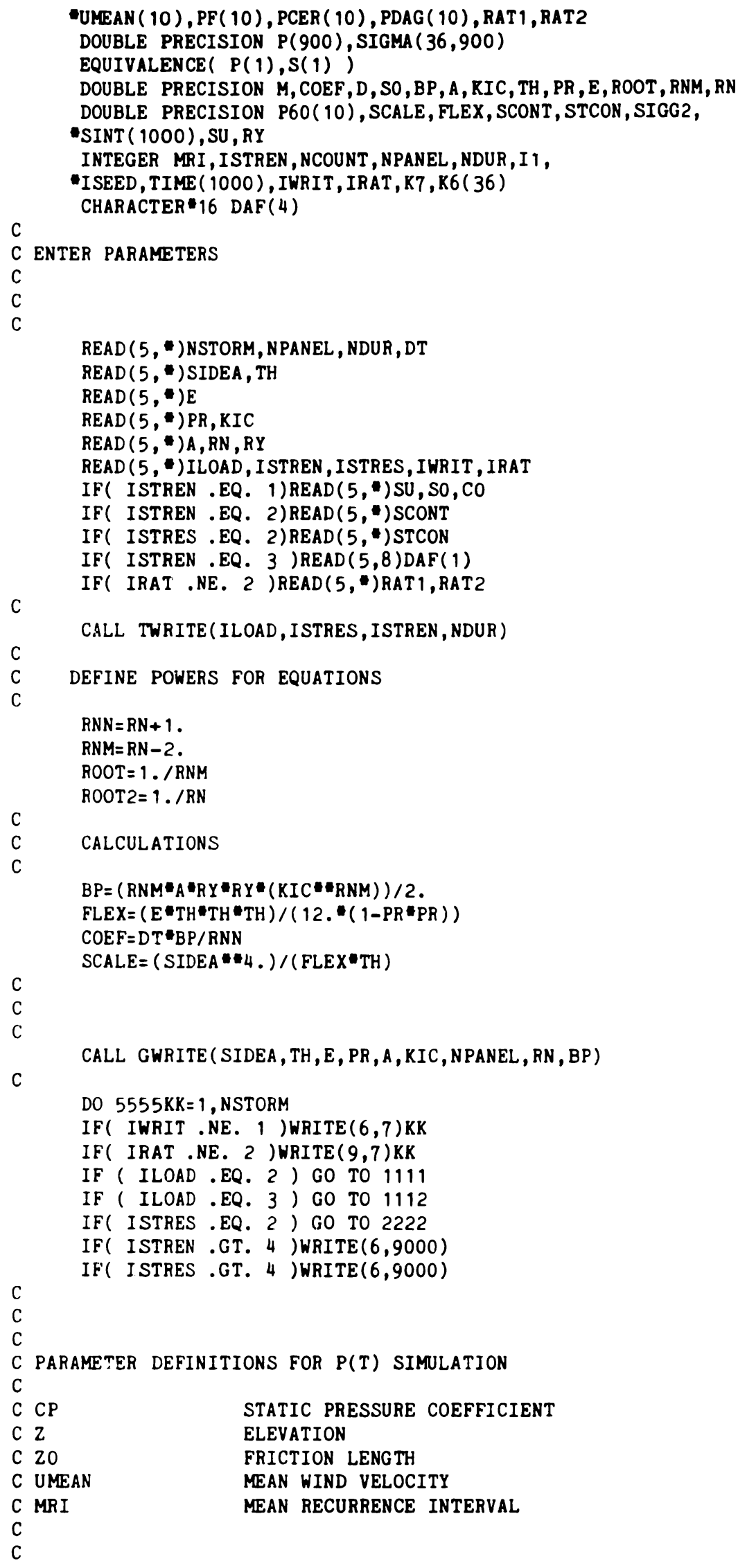




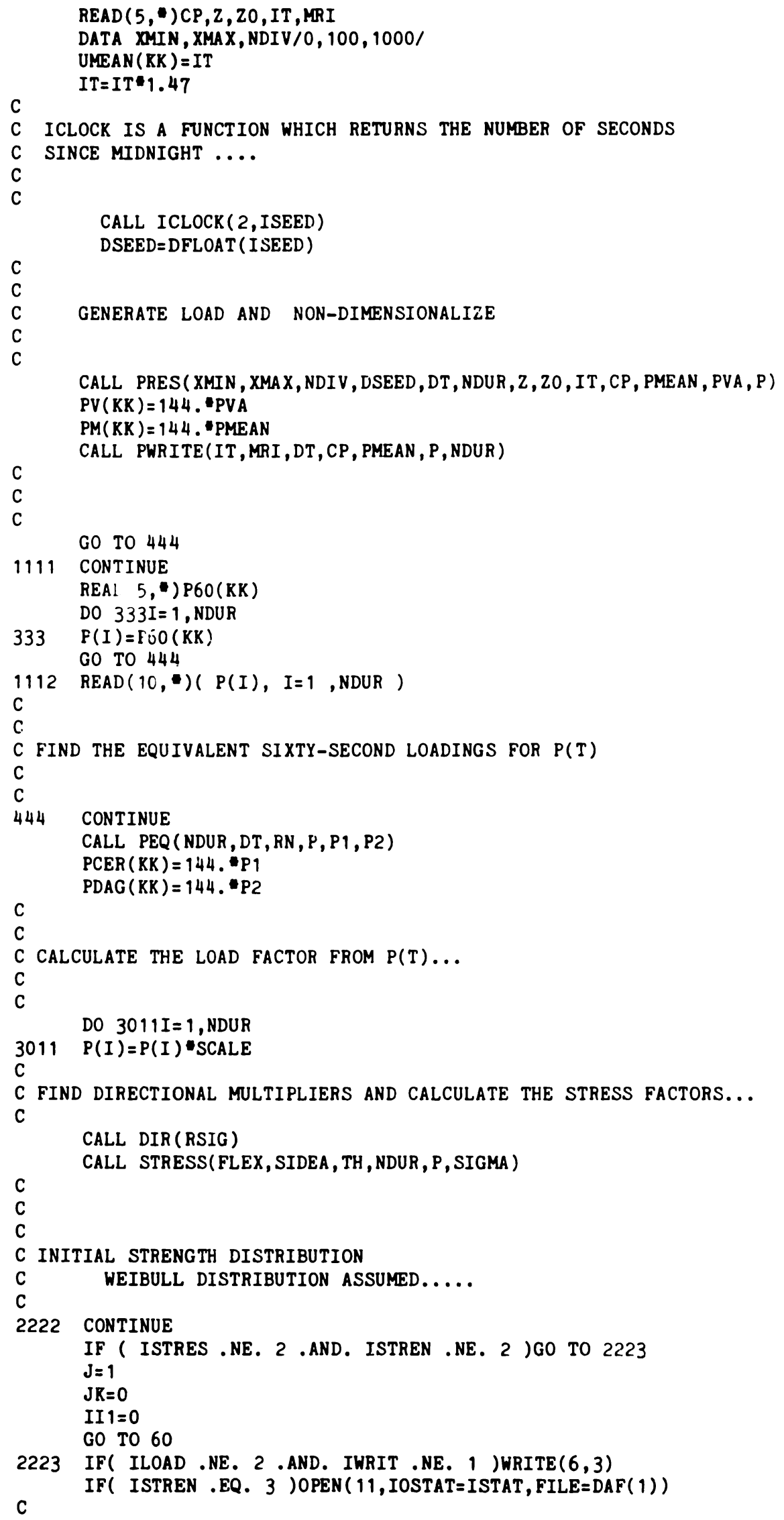




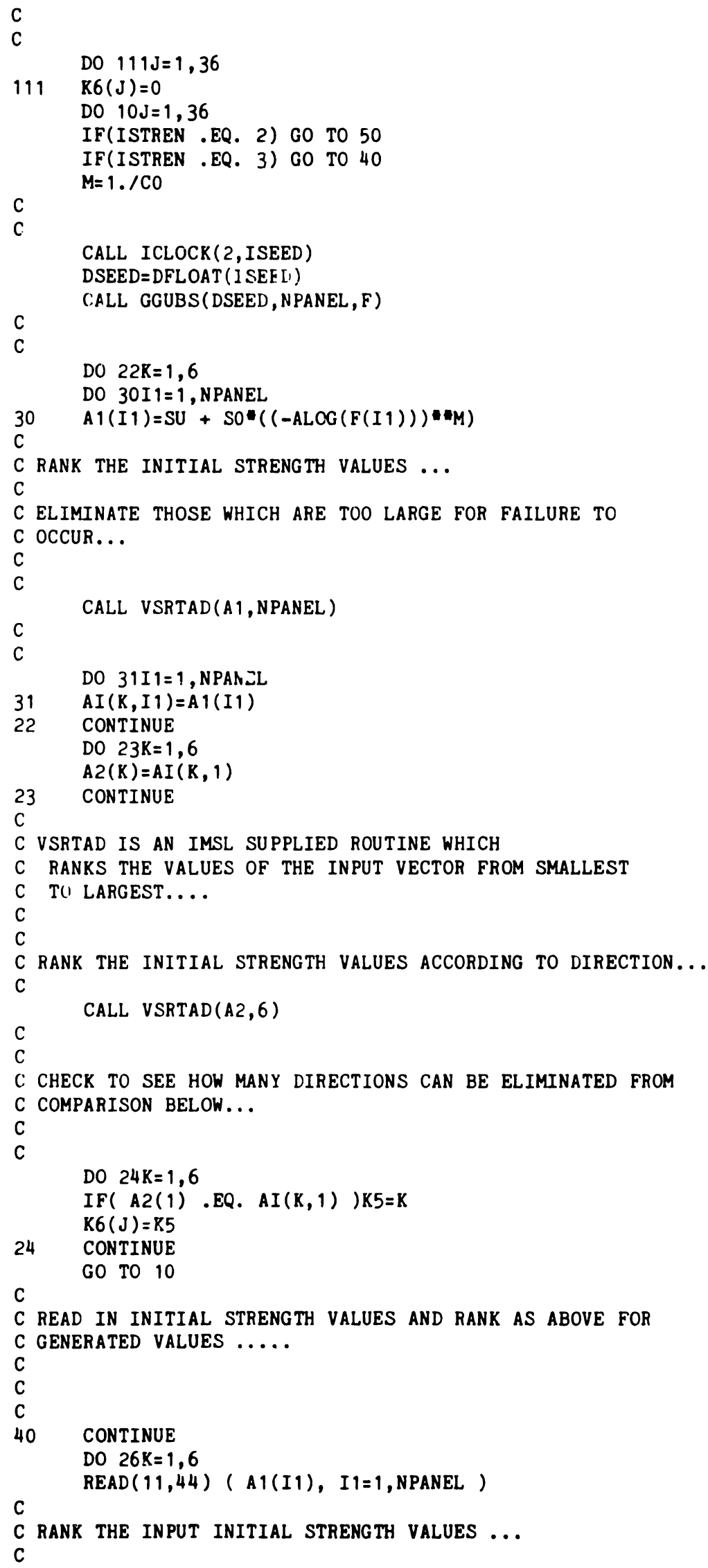




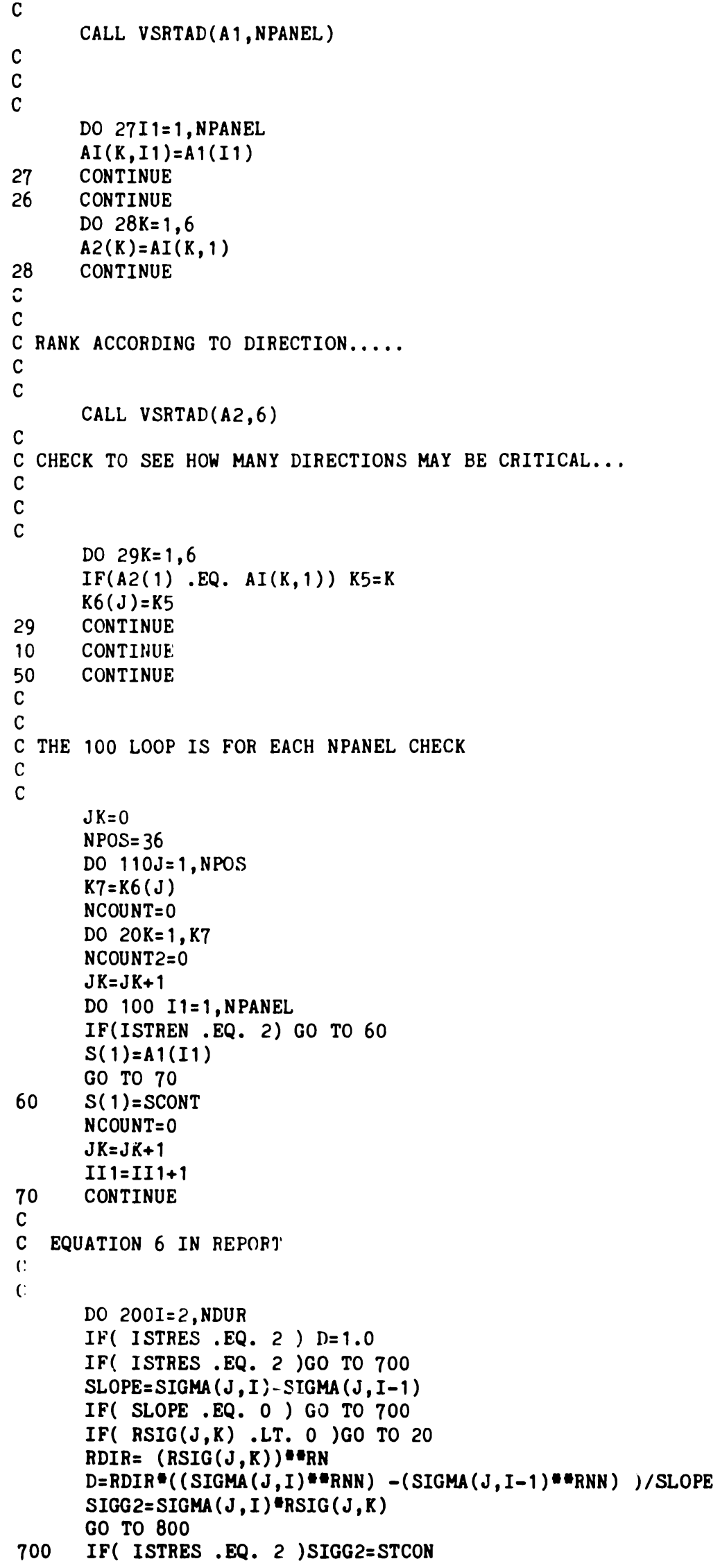




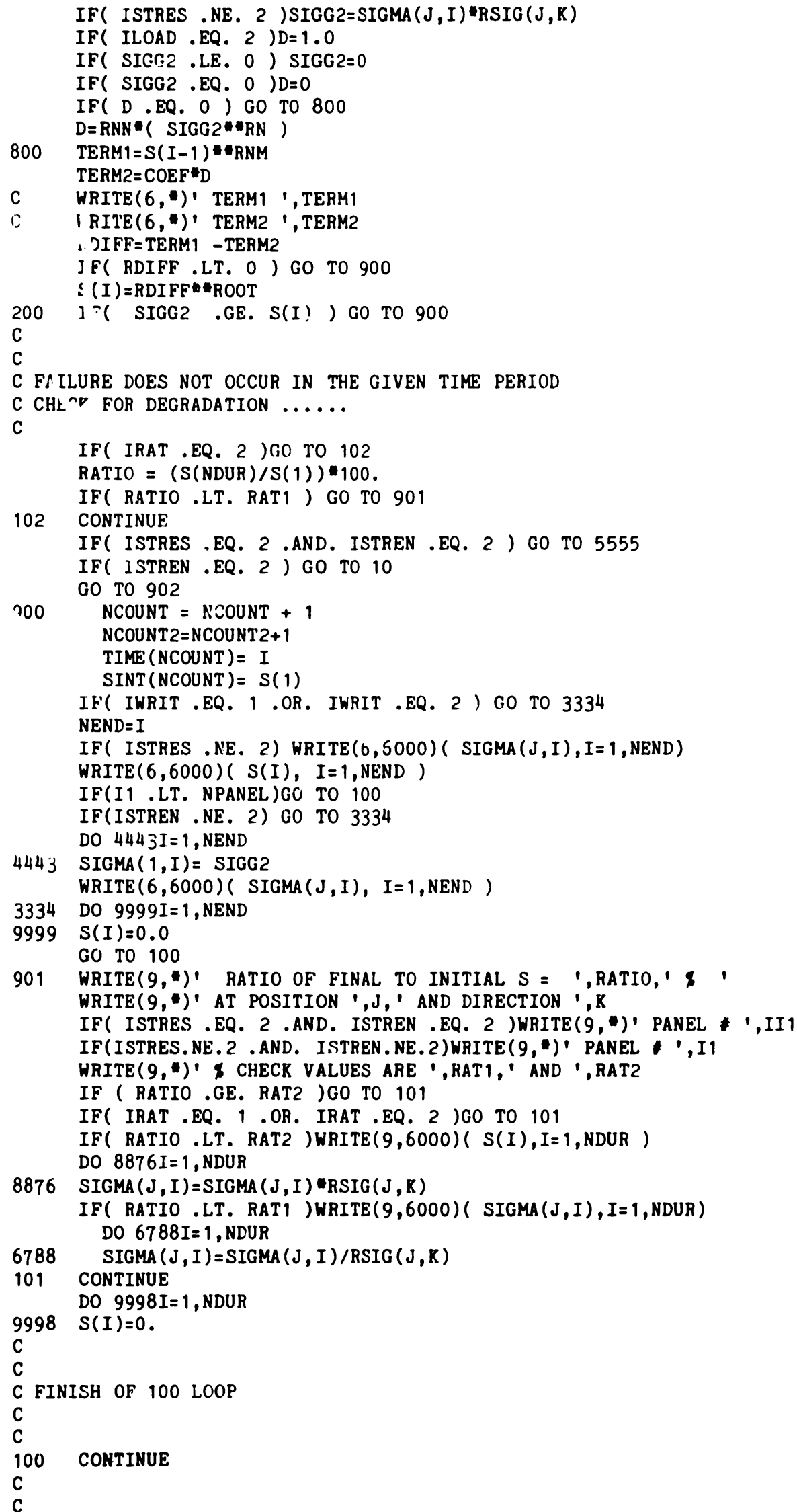




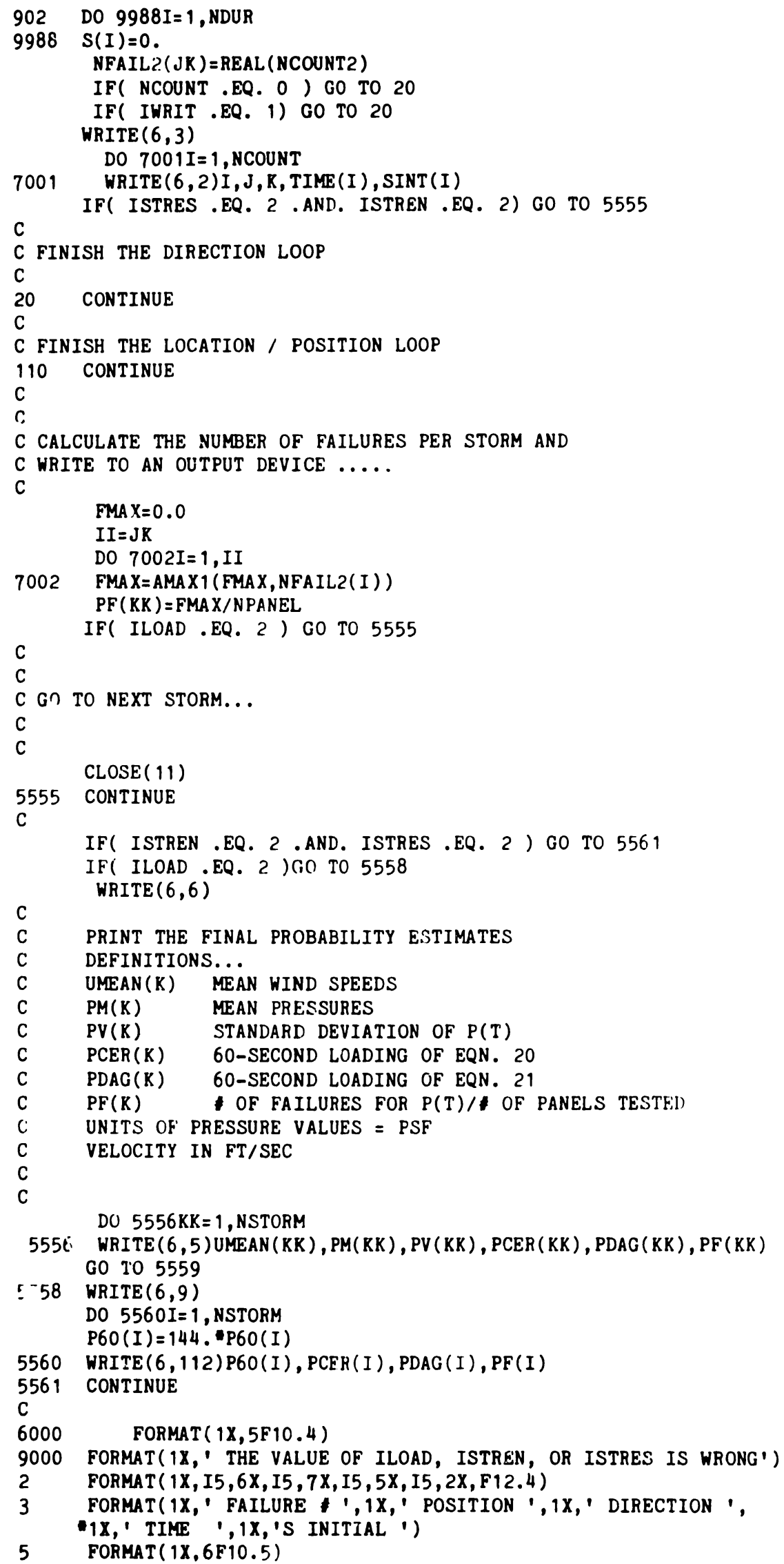




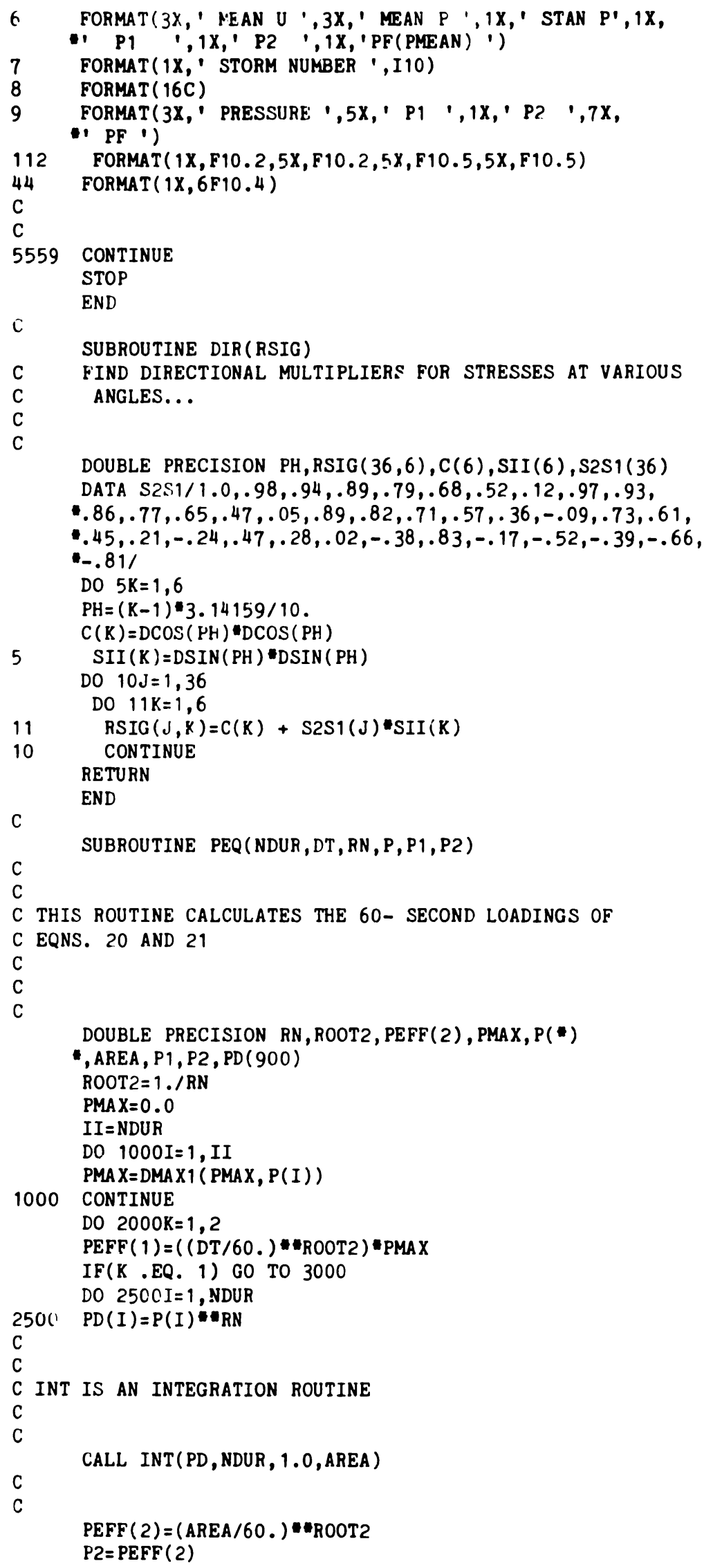




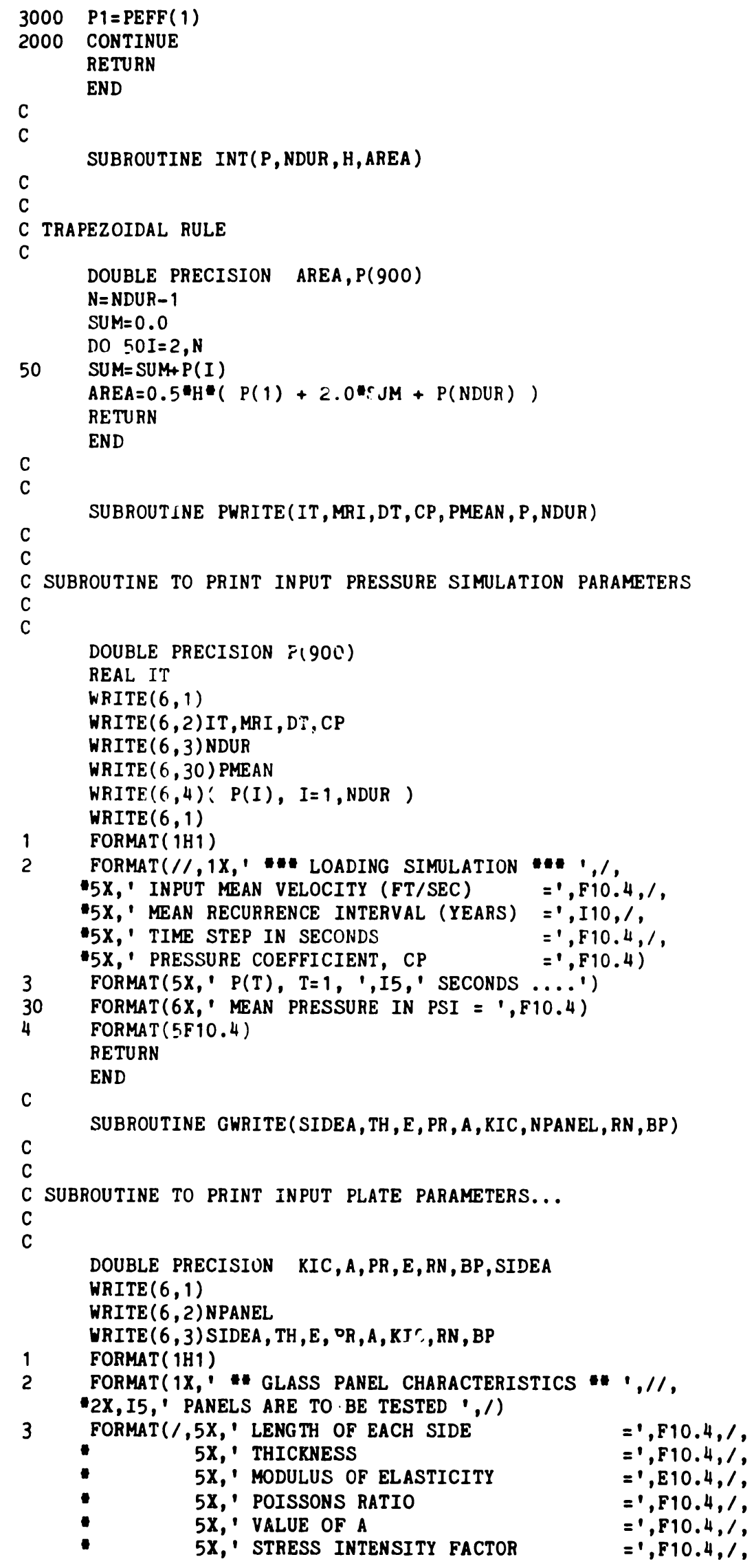




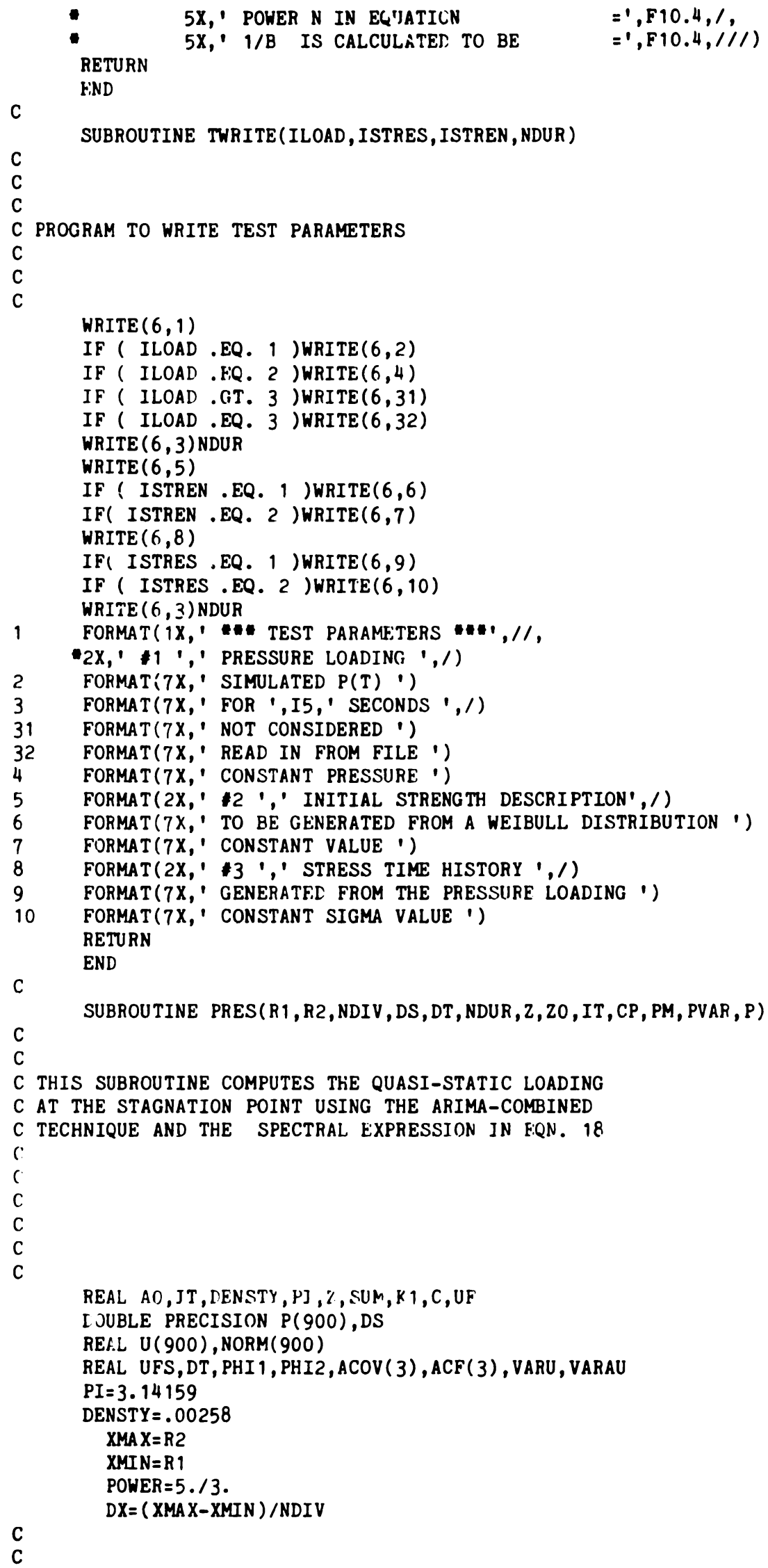




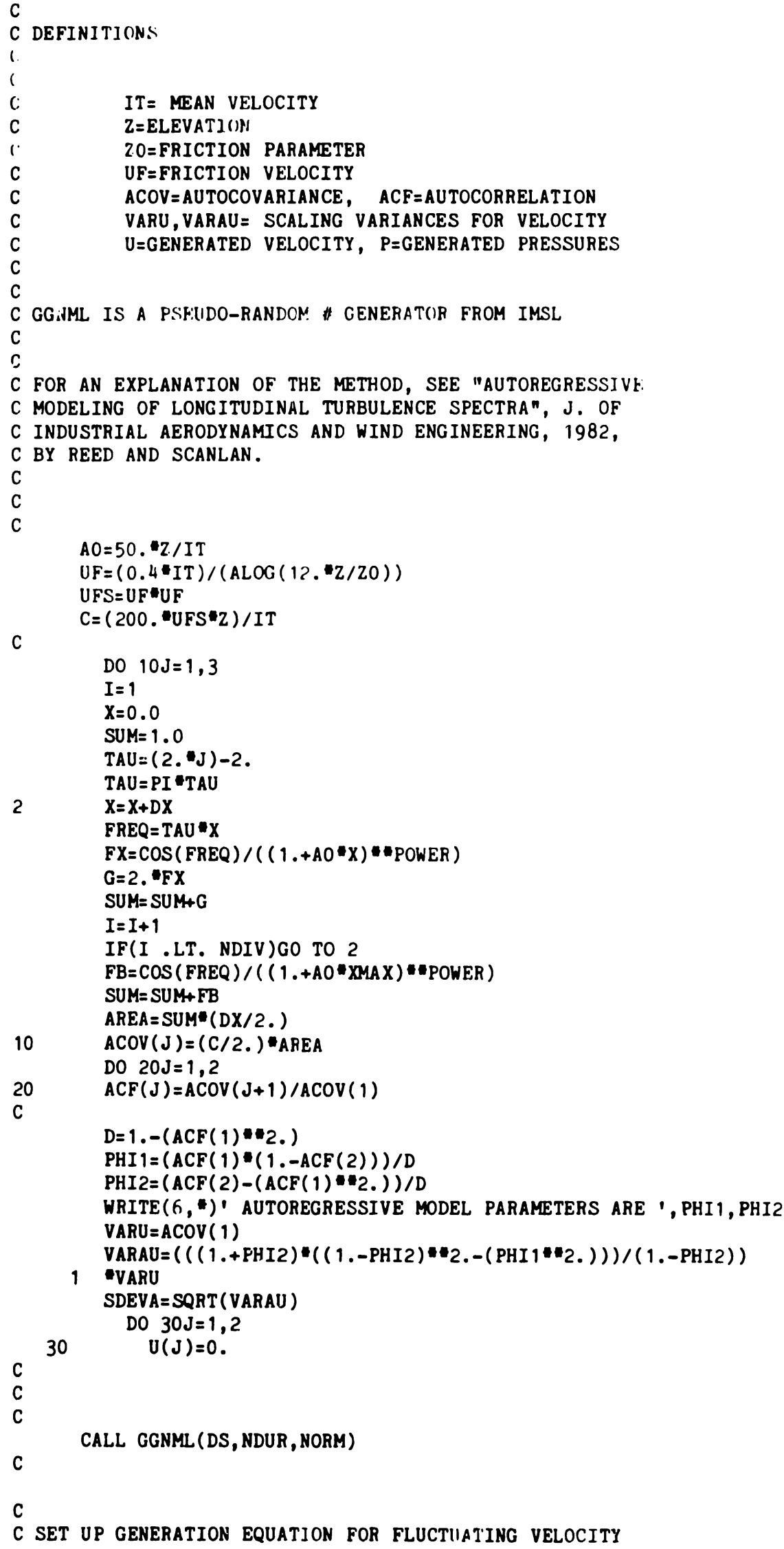




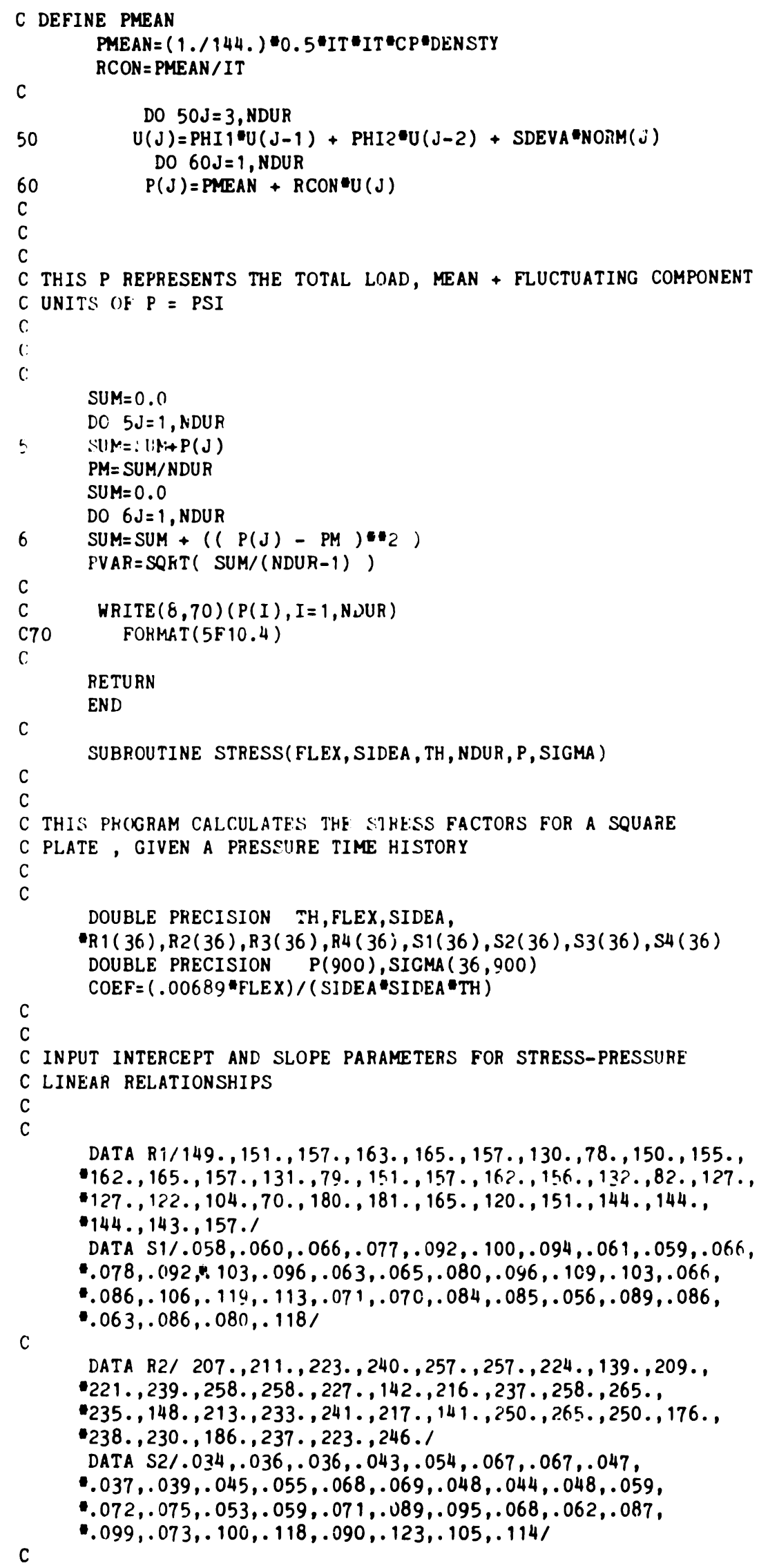


DATA R3/310,,319.,333., 370, 420, 457, 426., 279.,320., $-337 ., 374 ., 425 ., 463 ., 435 \ldots, 286 ., 349 ., 381 \ldots, 436 \ldots, 482$., $460 \ldots, 307 ., 392$, 445.,507 .,502., 345.,436.,525.,549.,

$-396 ., 539 ., 583 ., 457 ., 607 ., 607 ., 587.1$

DATA S3/.019,.018,.019,.023,.032,.045,.053,.038,.022,

$.023, .025, .034, .047, .053, .039, .028, .031, .037, .049, .055$,

$.041, .038, .042, .052, .060, .046, .050, .057, .070, .058, .058$,

C

$\bullet .083, .077, .096, .082, .105 /$

DATA R4/407.,410.,430.,484,,581,,687.,689.,471.,428.,

$454 ., 500, .593 ., 697 ., 700,, 480,, 490,, 538 ., 620 ., 725 ., 735 .$,

$-511 ., 584 ., 656 \ldots 769 ., 803 ., 576 \ldots, 688 \ldots, 812 \ldots, 901 ., 688 ., 827$. ,

$998 ., 843 ., 1086 ., 1016 ., 1114.1$

DATA S4/.029,.029,.027,.026,.032,.042,.049,.036,.030,.031,

$.029, .032, .041, .048, .037, .033, .034, .034, .042, .049, .037$,

$.037, .038, .043, .050, .039, .044, .046, .056, .048, .038, .064$,

$.064, .072, .085, .110 /$

C

C

DO $200 I=1$, NDUR

IF(P(I).LE. 1000)GO TO 3

IF(P(I) .GT. 1000 .AND. $P(I)$.LE. 2000) GO TO 4

IF( $P(I)$.GT. 2000 .AND. P(I) .IF. 50(I) GO TO 5

IF(P(I) .GT. 5000 .AND. $P(I)$.LF. 10000) GO TO 6

IF(P(I) .GT. 10000) GO TO 7

$\mathrm{C}$

\section{CONTINUE}

$\operatorname{SIGMA}(1, I)=\operatorname{COEF}\left(202-\operatorname{DLOG}(P(I)) \cdot\left(99.6-13.3^{* D L O G}(P(I))\right)\right)$

$\operatorname{SIGMA}(9, I)=\operatorname{SIGMA}(1, I)$

$\operatorname{SIGMA}(16, I)=\operatorname{SIGMA}(1, I)$

$\operatorname{SIGMA}(22, I)=\operatorname{SIGMA}(1, I)$

$\operatorname{SIGMA}(2, I)=\operatorname{SIGMA}(1, I)$

$\operatorname{SIGMA}(3, I)=\operatorname{SIGMA}(2, I)$

$\operatorname{SIGMA}(10, I)=\operatorname{SIGMA}(2, I)$

$\operatorname{SIGMA}(4, I)=\operatorname{COEF}(267-\operatorname{DLOG}(P(I)) \cdot(131-16.9 \cdot \operatorname{DLOG}(P(I))))$

$\operatorname{SIGMA}(11, I)=\operatorname{SIGMA}(4, I)$

$\operatorname{SIGMA}(17, I)=\operatorname{SIGMA}(4, I)$

$\operatorname{SIGMA}(5, I)=\operatorname{COEF}(441-\operatorname{DI} \cdot \operatorname{Jg}(P(I)) \cdot(201-23.5 * \operatorname{DLOG}(P(I))))$

$\operatorname{SIGMA}(12, I)=\operatorname{SIGMA}(5, I)$

$\operatorname{SIGMA}(18, I)=\operatorname{SIGMA}(5, I)$

$\operatorname{SIGMA}(23, I)=\operatorname{SIGMA}(5, I)$

$\operatorname{SIGMA}(6, I)=\operatorname{COEF}(676-\operatorname{DLOG}(P(I)) *(292-31.6 \cdot \operatorname{DLOG}(P(I))))$

$\operatorname{SIGMA}(13, I)=\operatorname{SIGMA}(6, I)$

$\operatorname{SIGMA}(19, I)=\operatorname{SIGMA}(6, I)$

$\operatorname{SIGMA}(24, I)=\operatorname{SIGMA}(6, I)$

$\operatorname{SIGMA}(28, I)=\operatorname{SJGMA}(6, I)$

$\operatorname{SIGMA}(7, I)=\operatorname{COEF} *(4.96+.130 * P(I))$

$\operatorname{SIGMA}(14, I)=\operatorname{SIGMA}(7, I)$

$\operatorname{SIGMA}(20, I)=\operatorname{SIGMA}(7, I)$

$\operatorname{SIGMA}(25, I)=\operatorname{COEF}(27.4+.0790 * P(I))$

$\operatorname{SIGMA}(29, I)=\operatorname{COEF}(30.2+.0885 * P(I))$

$\operatorname{SIGMA}(32, I)=\operatorname{COEF}(36.1+.0969 * P(I))$

$\operatorname{SIGMA}(8, I)=\operatorname{COEF}(1.93+.0785 \cdot P(I))$

$\operatorname{SIGMA}(15, I)=\operatorname{SIGMA}(8, I)$

$\operatorname{SIGMA}(21, I)=\operatorname{SIGMA}(8, I)$

$\operatorname{SIGMA}(26, I)=\operatorname{COEF}(2.70+.0384 * P(I))$

$\operatorname{SIGMA}(30, I)=\operatorname{COEF}^{*}(6.52+0.109 \cdot P(I))$

$\operatorname{SIGMA}(33, I)=\operatorname{COEF}(8.37+.120 \cdot F(I))$

$\operatorname{SICMA}(35, I)=\operatorname{COEF}(7.93+.142 \cdot P(I))$

$\operatorname{SIGMA}(36, I)=\operatorname{COEF} *(7.07+0.156 * P(I))$

$\operatorname{SIGMA}(27, I)=\operatorname{SIGMA}(36, I)$

$\operatorname{SIGMA}(31, I)=\operatorname{SIGMA}(36, I)$

$\operatorname{SIGMA}(34, I)=\operatorname{SIGMA}(36, \mathrm{~J})$ 


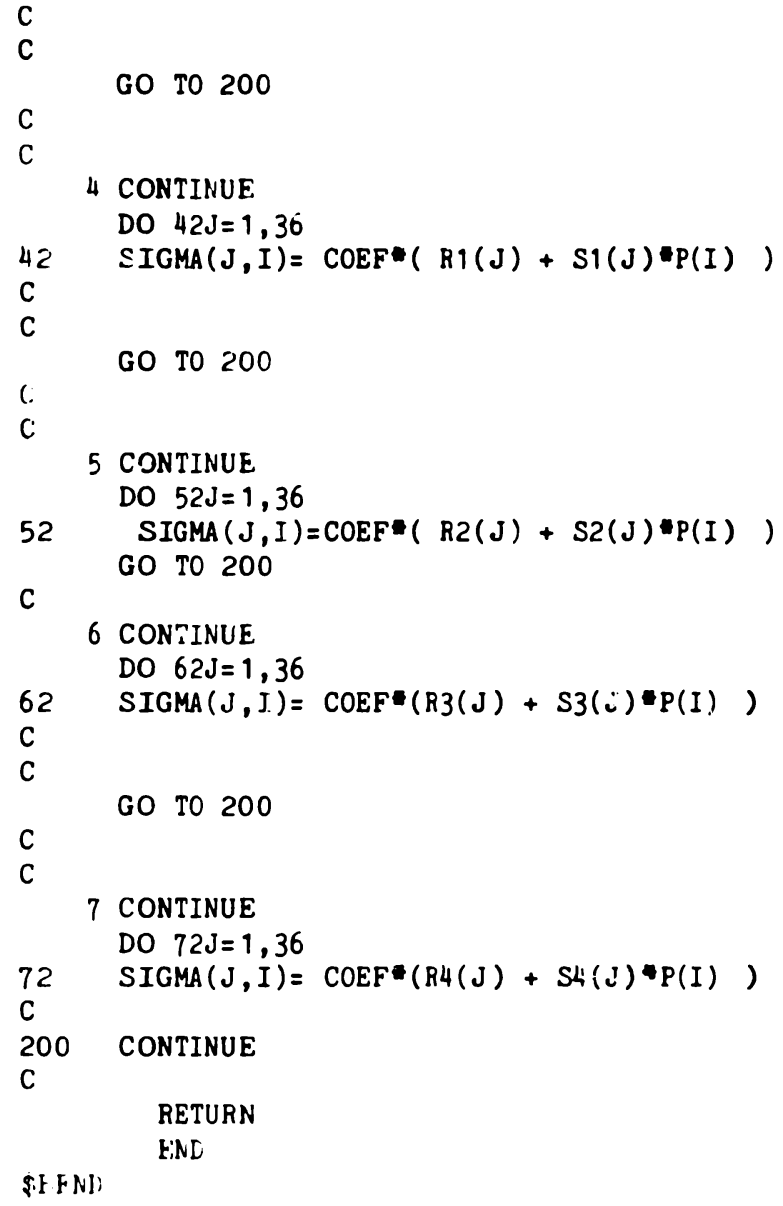


Table 1. Estimated Probabilities of Fallure Based on Stress Time History, and on 1-Minute Loads Estimated in Accordance with References 12 and 3. Units of pressure $=$ psf.

\begin{tabular}{cccccc}
\hline $\bar{p}$ & $\begin{array}{c}\mathrm{C} \\
\mathrm{P}_{60}\end{array}$ & $\mathrm{P}_{60}$ & $\mathrm{P}_{\mathrm{f}}(\overline{\mathrm{p}})$ & $\mathrm{P}_{\mathrm{f}}\left(\mathrm{P}_{60}=\mathrm{P}_{60}^{\mathrm{C}}\right)$ & $\mathrm{P}_{\mathrm{f}}\left(\mathrm{P}_{60}=\mathrm{P}_{60}\right)$ \\
\hline 10 & 10.8 & 12.6 & 0.001 & 0.002 & 0.003 \\
\hline 15 & 16.2 & 18.9 & 0.015 & 0.004 & 0.008 \\
\hline 20 & 21.6 & 25.2 & 0.050 & 0.012 & 0.022 \\
\hline 30 & 27.0 & 31.5 & 0.150 & 0.035 & 0.069 \\
\hline
\end{tabular}




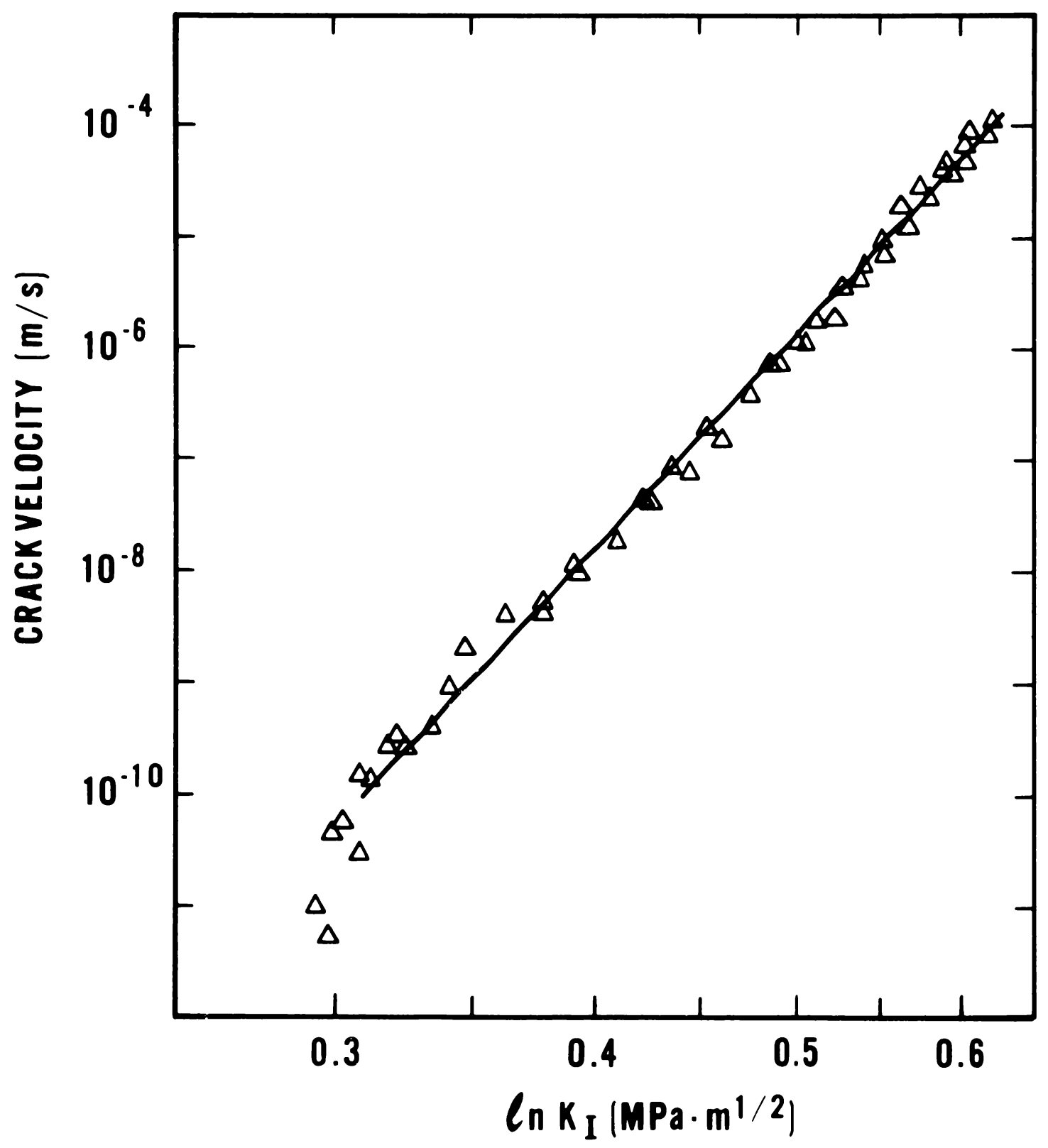

Figure 1. Crack velocity vs. $\ell n\left(K_{I}\right)$ for soda-1ime silica glass [23] 


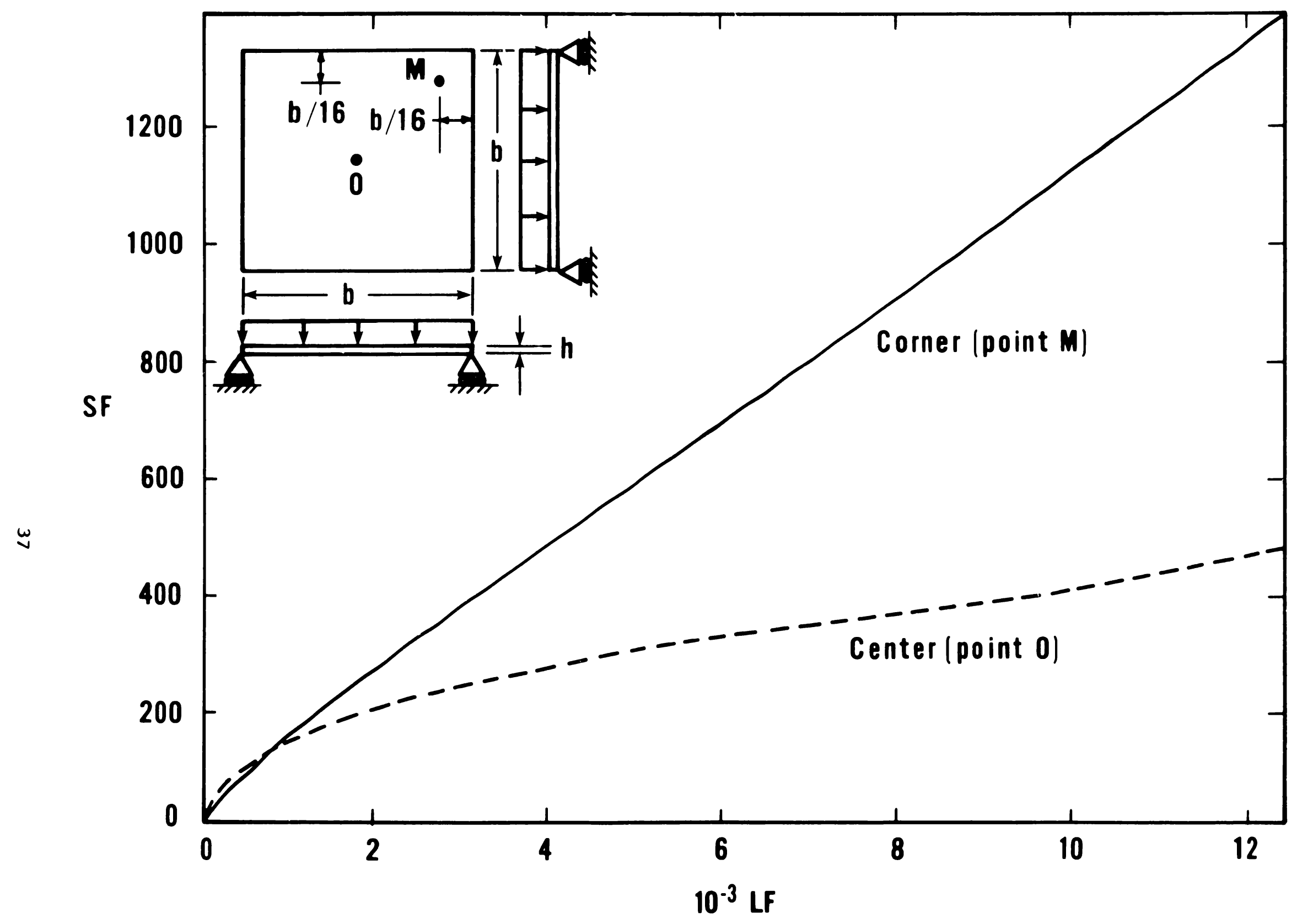

Figure 2. Center and corner maximum principal stresses for a square plate 


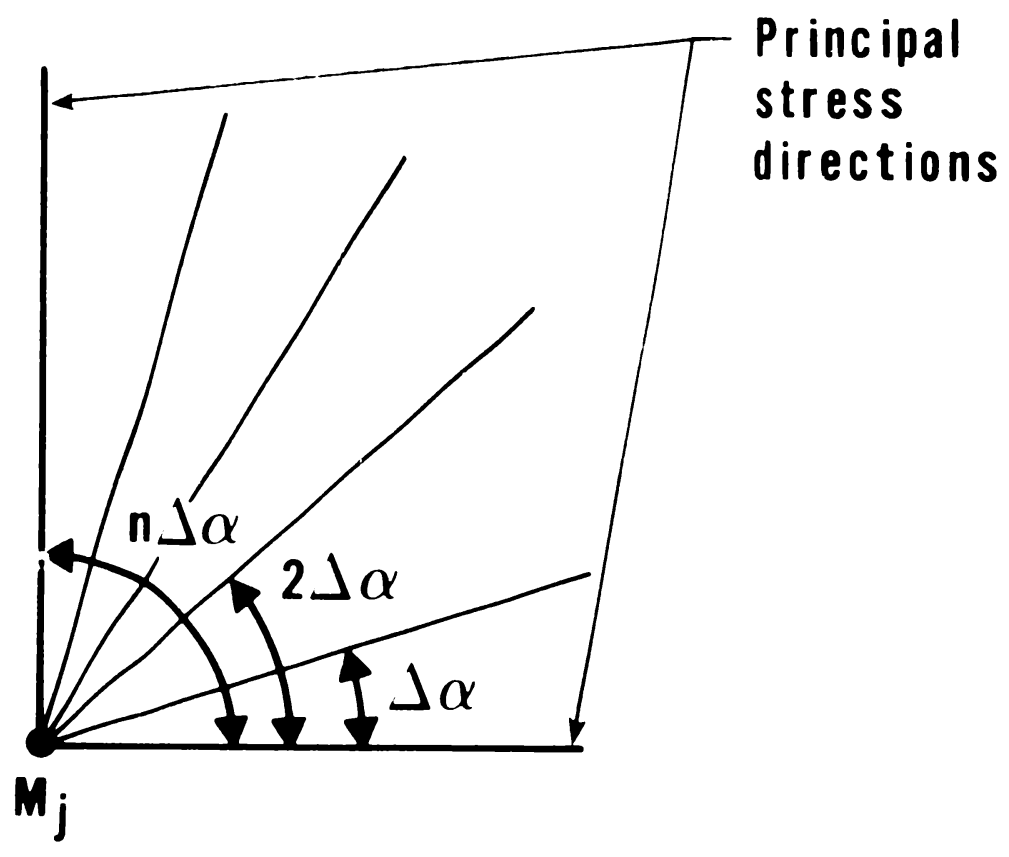

F1gure 3. Schematic representation of angles $\alpha_{k}=k \Delta \alpha$ 


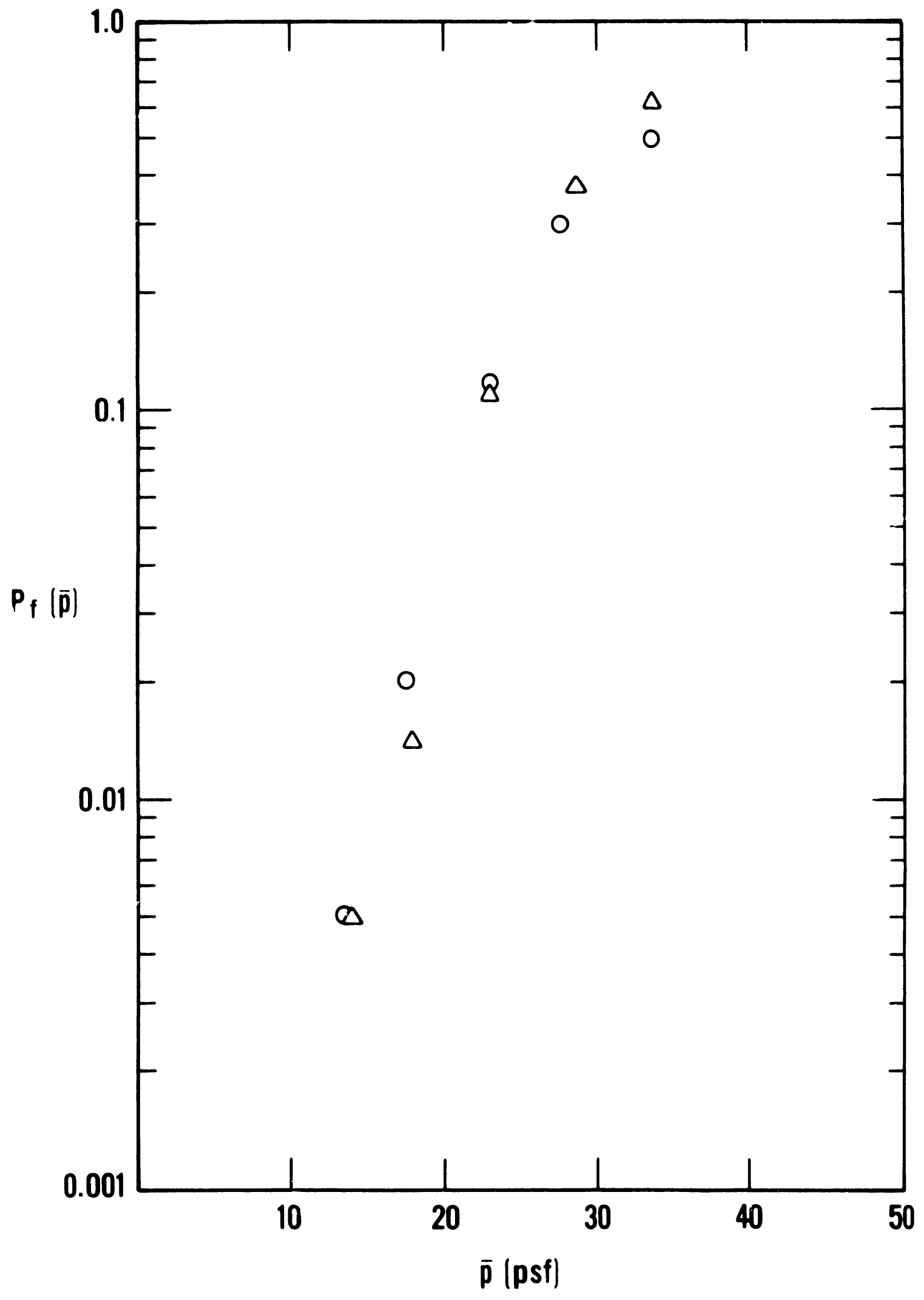

Figure 4. Cumulative distribution function for $p(t)$ 

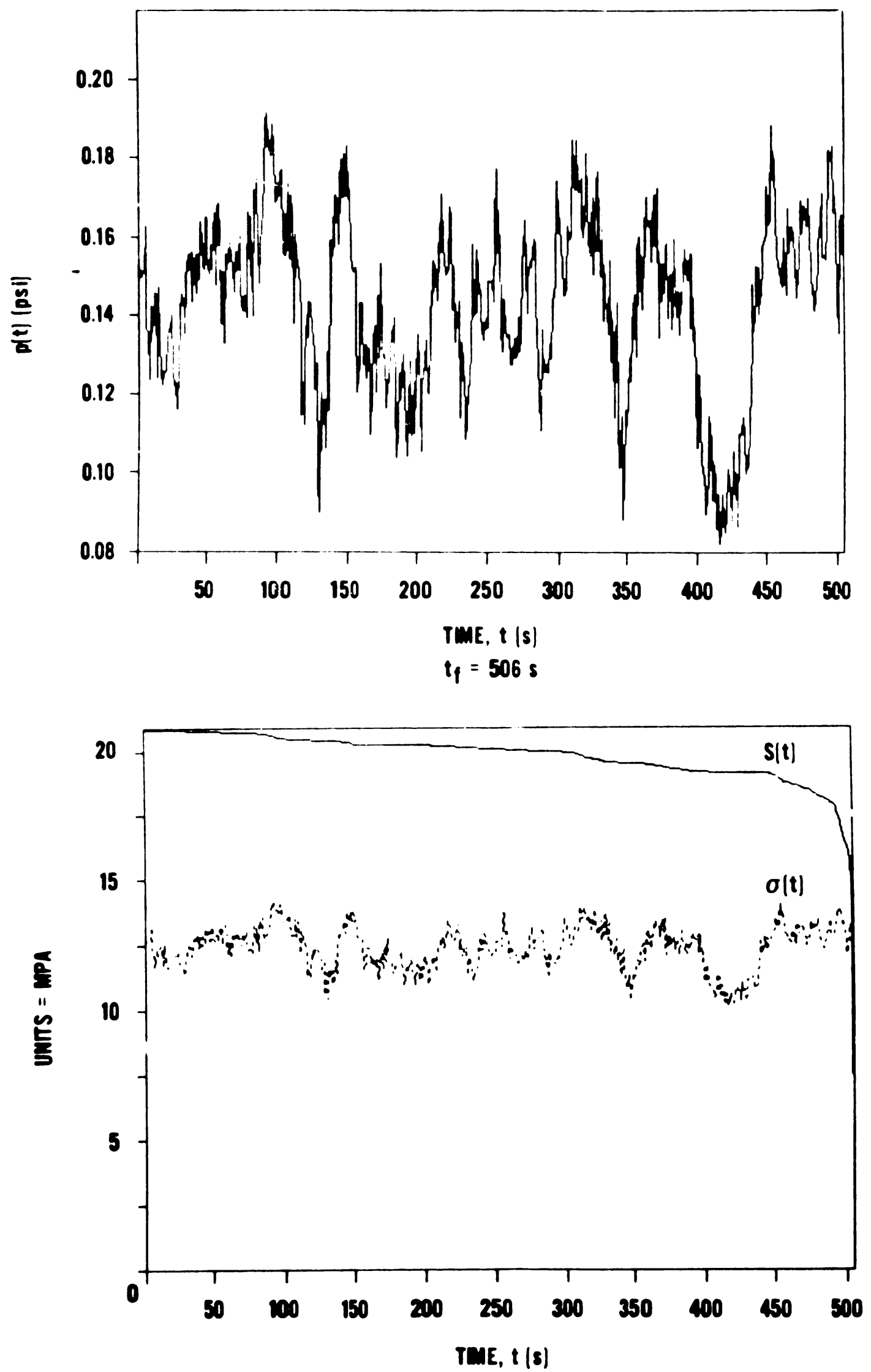

Figure 5. Evolution of strength and stresses with time for breaking panel 40 


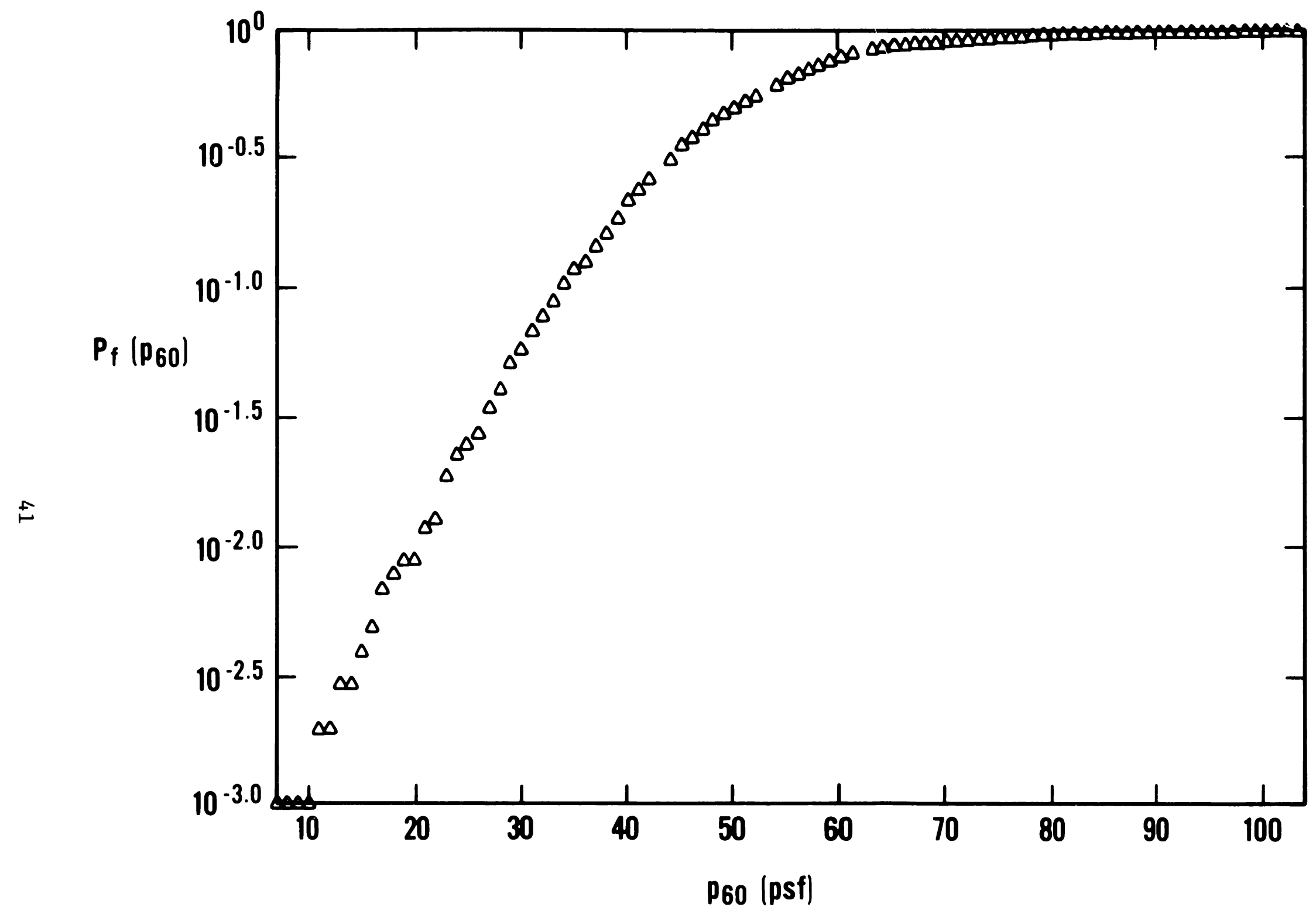

Figure 6. Cumulative distribution function for p60 
4. TITLE AND SUBTITLE

Wind Loading and Strength of Cladding Glass

5. AUTHOR(S)

D. A. Reed and E. Simiu

6. PERFORMING ORGANIZATION (If joint or other than NBS, see instructions)

MATIONAL BUREAU OF STANDARDS

DEPARTMENT OF COMMERCE

WASHINGTON, D.C. 20234

ContracuGrant No.

9. SPONSORING ORGANIZATION NAME AND CO::PLETE ADDRESS (Street. City. Stote, ZIP)

8. Type of Report \& Period Covered Fina1

Same as in item 6 above.

10. SUPPLEMENTARY NOTES

Library of Congress Catalog Card Number: 83-500515

[] Document describes a computer program; SF-185, FIPS Software Summary, is attached.

11. ABSTRACT (A 200-word or less factual summary of most significant information. If document includes o significont bibliography or literature survey. mention it here)

A procedure for 1nvestigating glass cladding behavior under arbitrary loads, including fluctuating wind loads, is presented. The procedure accounts for the $f p-t$ that internal stresses are nonlinear functions of the external loads, that intial glass strengths are random functions of position and direction, and that glass strength undergoes degradation under the action of external loads in accordance with basic fracture mechanics laws. Numerical examples are presented, and corresponding probability distribution curves are calculated, Indicating the probability of fallure of a specified panel subjected to fluctuating wind loads and to 1 -minute constant loads. These curves are used to illustrate a method for assessing current glass cladding design procedures. For the case considered in the paper, it was found that transformation of the peak wind load averaged over 1-2 seconds into an equivalent 1-minute load appears to underestimate the probability of fallure of glass cladding. The work reported in the paper is part of an ongoing window cladding research program being conducted at the National Bureau of Standards.

12. KEY WORDS (Six to twelve entries; alphabetical order: copitalize only proper nomes; ond seporate key words by semicolons) aerodynamics; buildings; deformation; engineering mechanics; failure; glass; loads (forces); probability theory.

13. AVAILABILITY

[X] Unlimited

For Official Distribution. Do Not Release to NTIS

[X] Order From Superintendent of Documents, U.S. Government Printing Office, Washington, D.C. 20402.

[.] Order From National Technical Information Service (NTIS), Springfield, VA. 2216I
14. NO. OF PRINTED PAGES

49

15. Price

$\$ 4.00$ 


\section{NBS TECHNICAL PUBLICATIONS}

\section{PERIODICALS}

JOURNAL OF RESEARCH-The Journal of Research of the Nalional Bureau of Standards repor's NBS research and develop. ment in those disciplines of the physical and engineering sciences in which the Bureau is aclive These include physics, cheniistry. engineering. mathemalics, and computer sciences Papers cover a broad range of subjects. with major emphasis on measurement methodology and the basic technology underlying standardization Also included from lime to lime are survey articles on lopics closely related to the Bureau's technical and scientific programs As a special service to subscribers each issue contains complete citalions to all recent Bureau publications in both NBS ano non NBS media lssued six limes a year Annual subscription domestic S18: foreign $\$ 22$ \$0 Single copy. $\$ 590$ domestic: 5690 foreign

\section{NONPERIODICALS}

Monozraphe-- Major contributions to the lechnical literature on variour subjects related to the Bureau's scientific and technical ac!lvilies

Handrooks-Recommended codes of engineering and industrial praclice (including safely codes) developed in co.speration with in terested industries. professional organizations. and regulatory bodies

Special Pulication - Include proceedings of conferences spon. sored by NBS. NBS annual reports. and other special publications appropriate to this grouping such as wall charts. pocket card . and bibliographies

Apelled Martematics Series-Mathemalical tables, manuals, and studies of special interest to physicists, engineers, chemists, biclogists. mathematicians. computer programmers, and others engaged in scientific and rechnical work

National Stamard Refereace Data Series-Provides quantilulive dala on the physical and chemical properties of materials, com. piled from the world's litersture and critically evaluated Developed under a worldwide program coordinated by NBS under the authorils of the Valional Standard Dala Acl iPublic Law 90.3961

NOTE The principal publication outlet for the foregoing data is the Journal of Physical and Chemical Reference Data (JPCRD) published quarterly for NBS by the American Chemical Sociel! (ACS) and the American Institute of Physics (AIP) Suhscriptions. reprints, and supplerr.ents disilable from $A(S$. 11 ss Sixieenth $S i$ NU. Washingion. DC z0056
Deildim Scieace Series-Disseminates technical information developed at the Bureau on building materials, components, systems, and whole structures. The series presents research results. lest methods. and performance criteria related to the structural and environmental functions and the durability and safety charac. teristics of building elements and systems

Tectuical Notes-Studies or reports which are complete in them. selves but restrictive in their treatment of a subject. Analogous to monographs but not so comprehensive in scope or defin!tive in treatment of the subject area. Often serve as a vehicle for final repurts of work performed at NBS under the sponsorship of other government agencies

Voluontary Product Standards-Developed under procedures published by the Department of Commerce in Part 10. Tille 15, of the Code of Federal Regulations The standards establish nationally recognized requirements for products. and provide all concerned interests with a basis for common understanding of the characteristics of the products NBS administers this program as a supplement to the activilies of the private sector standardizing organizations

Conemaner Information Series-Practical information, based on NBS research and experience. covering areas of interest to the consumer Easily understandable language and illustrations provide useful background knowledge for shopping in today's lech. nological markelplace

Order the stove NBS puhlicalions from Superintendent of Documenti. Government Printing Office. Washington. DC 20402

Order the followine NBS publicalions-FIPS and NBSIR's-from the National Technical Information Service. Springfield. VA 22161

Federal Information Procesaias Standards Publication (FIPS P( B)-Publications in this series collectively constitute the Federal Information Processing Standards Register. The Register serves as the official source of information in the Federal Government regarding standards issued by NBS pursuant to the Federal Properly and Administralive Services Act of 1949 as amended. Public Lau 89.306 (79 Stat. 1127), and as implemented by Ex. eculive Order 11717 (38 FR 12315, dated May 11, 1973) and Part 6 of Titie IS CFR (Code of Federal Regulations)

NBS Iateragency Reports (NBSIR)-A special series of interim or final reports on work performed by NBS for outside sponsors (both government and non-government) In general. initlal disiribution is handled by the sponsor. public distribution is by the Vational Technical Information Service. Springfield. VA 22161 . in puper copy or microfiche form 